\title{
The Hanford Site: An Anthology of Early Histories
}

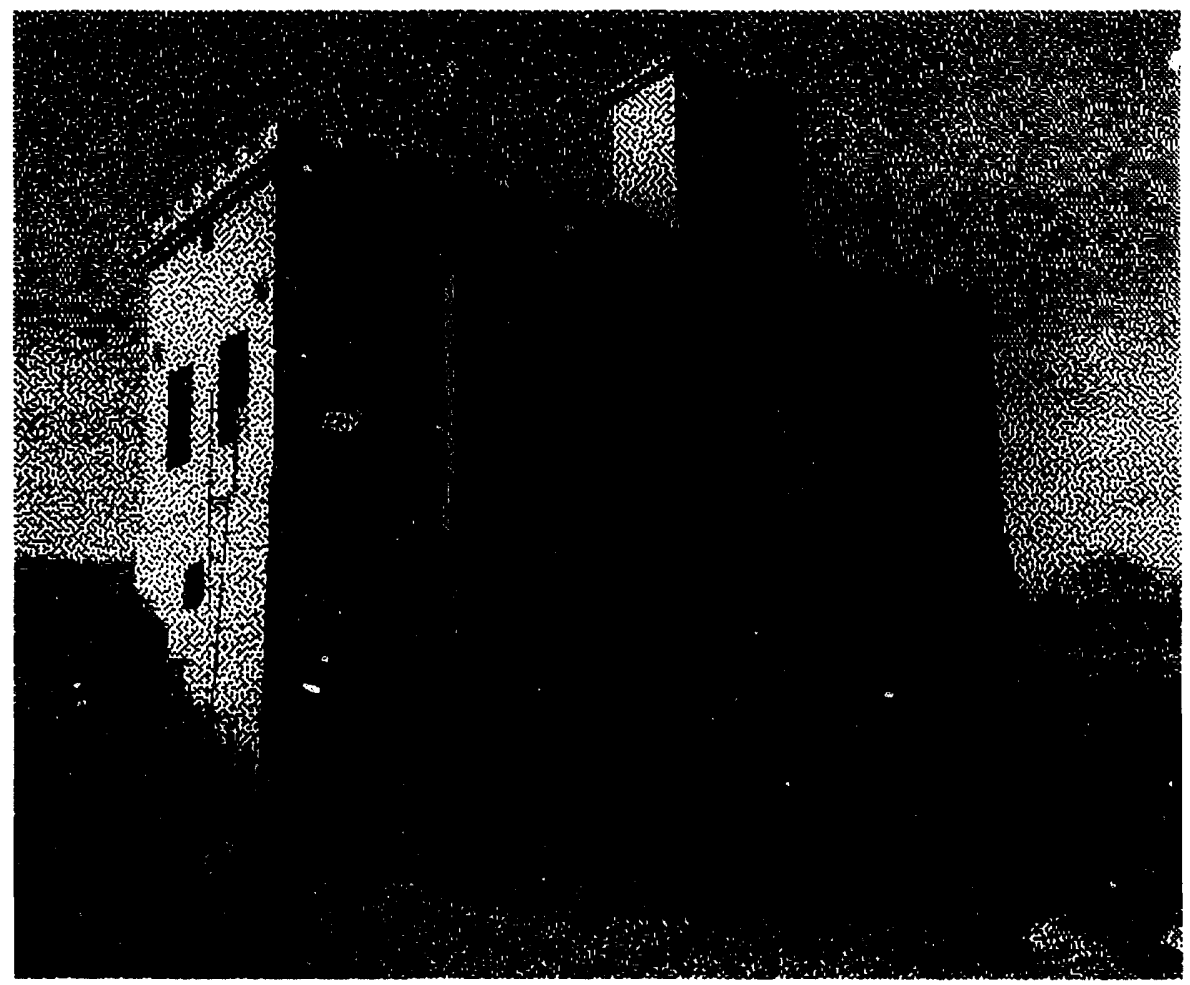

Prepared for the U.S. Department of Energy

Office of Environmental Restoration and Waste Management

\section{(2.) Westinghouse \\ Hanford Company Richland, Washington}

Hanford Operations and Engineering Contractor for the

U.S. Department of Energy under Contract DE-AC08-87RL10930 
This report was prepared as an account of work sponsored by an agency of the United States Government. Neither the United States Government nor any agency thereot, nor any of their employees, nor any of their contractors, subcontractors or their employees, makes any warranty, express or implied, or assumes any legal liability or responsibility for the accuracy, completeness, or any third party's use or the results of such use of any information, apparatus, product, or process disclosed, or represents that its use would not infringe privately owned rights. Reference herein to any specific commercial product, process, or service by trade name, trademark, manufacturer, or otherwise, does not necessarily constitute or imply its endorsement, recommendation, or favoring by the United States Government or any agency thereof or its contractors or subcontractors. The views and opinions of authors expressed herein do not necessarily state or reflect those of the United States Government or any agency thereot.

This report has been reproduced from the best available copy

Printed in the United State: of America

DISCLM-2.CHP (1-91)

The cover illustration depicts the Allard Pump House, which is located on the bank of the Columbia River between the 100-B and 100-K Areas on the present-day Hanford Site. Built by Judge Cornelius Hanford's Priest Rapids Irrigation and Power Company in 1908, the station furnished water to the earliest irrigation efforts in and around the towns of White Bluffs and Hanford. It also served as a prime supplier of water to the initial construction activities of the Hanford Engineer Works in 1943. 


\title{
The Hanford Site: An Anthology of Early Histories
}

\author{
M. S. Gerber \\ Date Published \\ October 1993
}

Prepared for the U.S. Department of Energy Office of Environmental Restoration and Waste Management

\section{(W) Westinghouse P.O. Box 1970}

(W) Hanford Company Richland, Washington 99352 


\section{RELEASE AUTHORIZATION}

Document Number: WHC-MR-0435

Document Title: The Hanford Site: An Anthology of Early Histories

Release Date: $\quad 11 / 9 / 93$

$* * * * * * * * * * * * *$

This document was reviewed following the procedures described in WHC-CM-3-4 and is:

\section{APPROVED FOR PUBLIC RELEASE}

$* * * * * * * * * * * * *$

IRA Specialist:




WHC-MR-0435

\section{Contents}

Memories of War: Pearl Harbor and the Genesis of the

Hanford Site ............................ 3

Safety Has Always Been Promoted at the Hanford Site . . . . . . . . . . . . 7

Women Have an Important Place in Hanford Site History . . . . . . . . . . . . 11

The Boom and Bust Cycle: A 50-Year Historical Overview

of the Economic Impacts of Hanford Site Operations on

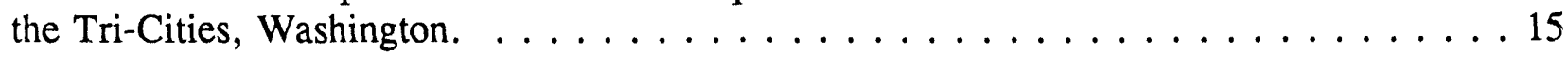

Hanford's Early Reactors Were Crucial to the Site's History . . . . . . . . . . . . . . 21

T-Plant Made Chemical Engineering History $\ldots \ldots \ldots \ldots \ldots \ldots$

The $\mathrm{UO}_{3}$ Plant Has a Long History of Service . . . . . . . . . . . . . . . . . 31

PUREX Plant: The Hanford Site's Historic Workhorse . . . . . . . . . . . . . . . . 37

PUREX Plant Waste Management Was a Complex Challenge . . . . . . . . . . . . 41

Early Hanford Site Codes and Jargon . . . . . . . . . . . . . . . . . . . . 47 




Hanford Engineer Works commander, Colonel Franklin Matthias, gives an impromptu press conference from his staff car at the conclusion of World War II in August 1945. 


\section{Memories of War: Pearl Harbor and the Genesis of the Hanford Site}

More than half a century has elapsed since the attack on Pearl Harbor, the startling event that propelled a divided and ambivalent America into total war. Much is being written on a national and worldwide scale about this historic occasion. But for workers at the Hanford Site, it has special importance, because Pearl Harbor was the seminal event that presaged the birth of this place - the largest ordnance plant in world history up to that point.

Before the explosive attack on December 7, 1941, the United States had witnessed more than six years of war in other parts of the world. In October 1935, Italian dictator Benito Mussolini invaded Ethiopia. In the summer of 1936, the Spanish Civil War broke out, producing Ernest Hemingway's classic, For Whom The Bell Tolls. This book, in the simple terms of human suffering, warned that when the bells of fascism tolled the death of a small country, the whole world was at risk. In September 1939, Hitler's armies overran Poland. Soon the Japanese moved against a China crippled by civil war, bombing Chungking and other cities into virtual paralysis. In June 1940, France fell to Nazi armies, and a year later the Germans turned against their sworn ally and invaded the Soviet Union. These events, together with the blitzkrieg over London, generated wary attention and a growing sense of unease in Americans. By October 1941, over 200 Allied ships (mostly English) had been sunk. That same month, the famous Reuben James became the first American warship to be sent to the bottom by Nazi U-boats (submarines) while escorting a convoy of the British Royal Navy.

The United States was already helping the Allies with massive materials programs such as the Destroyers-for-Bases Agreement and the Lend-Lease Act. This country instituted the first peacetime draft in its history in September 194O, and President Roosevelt declared a state of unlimited national emergency in May 1941. Still, there were many Americans who believed that the conflicts then boiling in the world were simply extensions of the power brokering and territorial struggles that had plagued Europe, Africa, and Asia for centuries. Why, they argued, should we send U.S. citizens to help one dictator, tribal king, or warlord oppose another? And so Americans watched the world, mesmerized by flickering newsreels narrated in flourishing phrases and voices, but still remained undecided. People got married, went to movies including Citizen Kane (the 1941 favorite), danced to Benny Goodman and Glenn Miller, and shopped for Christmas up to and including the abnormally balmy day of December 6 .

The next morning everything changed as innocence and isolationism ended; hurt and the instinct to defend 
one's home took over. Along Battleship Row, just off of Ford Island, inside snug and lovely Pearl Harbor, a few miles west of Honolulu, over half of the entire U.S. naval forces (four-fifths of the Pacific Fleet) were destroyed in less than three hours. Eighteen ships were sunk or seriously damaged, with the Arizona hit worst of all. Early in the attack, that vessel received a blast through the starboard side that went right into the magazines and aviation gasoline. Flames shot over 400 feet into the air, and the ship went down within minutes, killing 1,177 men (almost half of the total who died at Pearl that day). After the West Virginia sank, several men aboard were trapped in the forward pump room, where they lived until nearly Christmas. Despite rescue attempts, no one could reach them. Amidst the other burning ships, many died of burns and blast effects, some drowned, and some who survived got so much oil in their eyes that they could not see for days. 2,403 Americans died, 1,178 were wounded, and 347 planes were destroyed or disabled.

The U.S. responded swiftly, with a declaration of war the next day. The Japanese pressed forward with attacks on



Malaya, Thailand, Singapore, Hong Kong, Guam, Wake, Manila, Corregidor, Rabaul, and Borneo, all within five weeks. However, just six months after Pearl Harbor, the U.S. got its first Pacific victory in the Battle of Midway. There began the more than four year trek to reclaim the territory that Japan had taken so quickly.

Ironically, in the same month as the Pearl Harbor attack, the Uranium Committee of the federal Office of Scientific Research and Development (OSRD) decided to sponsor an intensive research project on plutonium, the strange new substance that had been isolated in a University of California Laboratory only nine months earlier. The OSRD placed the contract with the Metallurgical Laboratory (Met Lab) at the University of Chicago. From then on, the war proceeded on two tracks - the military track, which was reported in huge headlines around the world, and the scientific track, which was conducted entirely in secret.

In the same month as the Battle of Midway, the Army Corps of Engineers formed the Manhattan Engineer District (MED) to construct industrial-size plants

Hanford Engineer Works commander Colonel Franklin T. Matthias (left) and two contractor engineers assigned to the Hanford Site read the startling headlines that Hanford Engineer Works has been producing material for atomic weapons, August 1945. 
to manufacture the plutonium and uranium being investigated by Met Lab scientists. Six months later, just three days before Christmas 1942, as the nostalgic wartime song "White Christmas" was hitting Number One on the charts, Colonel Franklin T. Matthias and two engineers from the DuPont Corporation visited the future Hanford Site. On New Year's Eve 1942 , they reported to General Leslie R. Groves, chief of the Manhattan Project, that the Hanford region was "ideal in virtually all respects" (Matthias 1987) in terms of the criteria defined for the plutonium production site.

And so it went on two war fronts the battlefields and the home front of science and secrecy. Each had their milestones, their discomforts, their examples of extraordinary personal dedication, their near-misses, and their vast unknowns. And, throughout all the trials on the battle front and the home front, people on the ragged edge of exhaustion encouraged each other with the slogan, "remember Pearl Harbor." Whether shouted on a battlefield, or spoken softly with a nudge and a meaningful glance, these words inspired a whole nation of people and bound them together in common cause.

Looking back on December 7, 1941, what can we make of what we see? When



I was in high school, we were called to assembly every Pearl Harbor Day, to listen to fathers who were World War II veterans (and most of our fathers were) tell about their memories of war. That was less than 25 years after Pearl Harbor. Today, to high school students and to many of us at the Hanford Site, Worid War II seems as far away as the American Revolution. In photos of early Hanford, we see serious-looking men with slickedback hair and bulky clothes. We see squatlooking vehicles with huge rolling fenders and headlights that bulge forward like bug eyes. In our world of transistors and microchips and minivans, it is hard to imagine them building a place as macro as the Hanford Engineer Works (World War II name for Hanford Site).

Yet, they were real people, working under difficult conditions. They worked toward narrowly focused objectives, dictated by necessity, and they met every one of them. Evidence of their worldshaking accomplishments fills the Hanford Site - in the hulking, contaminated old buildings, and in the waste that workers endeavor to clean up. As they go about their job of finishing the production task, by cleaning up the old facilities and the waste, let us pause and recall the dire circumstances, the critical need, the harsh realities out of which the Hanford Site was born.

Major general Leslie R. Groves (right), chief of the entire Manhattan Project, presents the Army-Navy "E" Award, the highest civilian production award of World War II, to Dr. Bill Mackey, president of the DuPont Corporation (prime Hanford Engineer Works contractor at that time) in Richland, October 1945. 


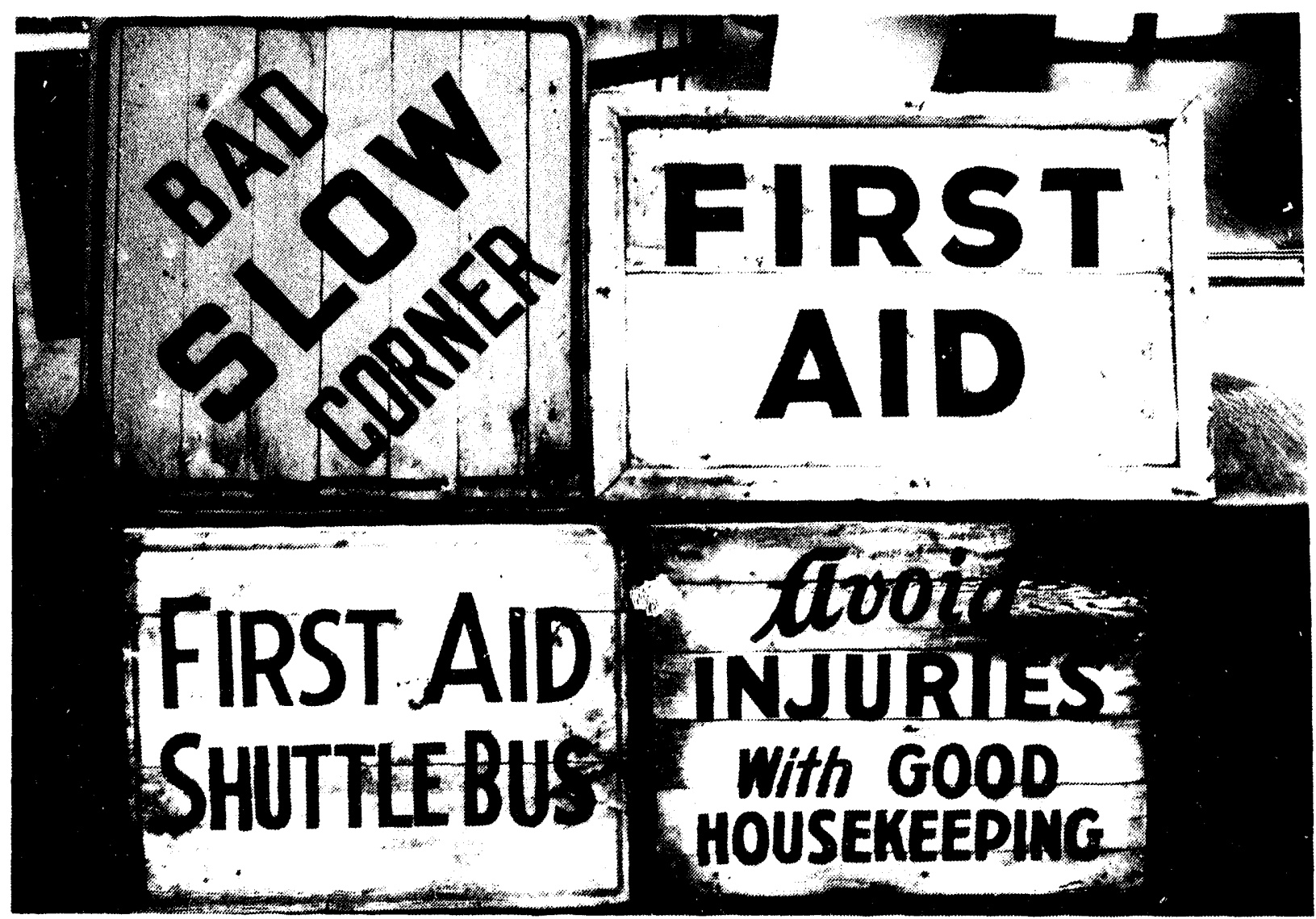

These are just a few examples of the large collection of Word War II era safety signs discovered on the Hanford Site in 1991. 


\section{Safety Has Always Been Promoted at the Hanford Site}

The use of safe procedures always has been a salient part of life at the Hanford Site. And the historical evidence is clear that these procedures worked. Consider the fact that approximately 1,500 buildings and 64 underground, highlevel waste tanks were constructed in less than two and one-half years at the Hanford Engineer Works, at the same time that the Site set accident-free records for the national construction industry. Then, in three extremely rapid postwar expansions between 1947 and 1955, hundreds of additional structures were erected, including huge and unique plants such as the REDOX Plant, the PUREX Plant, the $\mathrm{H}, \mathrm{DR}, \mathrm{C}, \mathrm{KW}$, and $\mathrm{KW}$ reactors, the Z-Plant (the Plutonium Finishing Plant), the C-Plant (a radiochemical pilot plant), seven complex new laboratories in the 300 Area, and 81 additional underground, high-level waste tanks. Additionally, other facilities on the Hanford Site were modified to accommodate new missions or expanded to more than double their output.

Throughout these years, safe practices were emphasized to the extreme. Vigorous safety campaigns were conducted in all Hanford Site areas and in Richland, with poor safety habits portrayed in cartoon form by "Hap Hazard" and other characters. Prizes and picnics were given for work groups that were successful in maintaining low injury and lost-work time records. For example, in June 1948, 100-F Area completed its third consecutive year without a lost-time injury, and a huge picnic was held for employees and their families.

In June 1946, Hanford Engineer works won the prime contractor's (DuPont Corporation's) "Awards for No Accidents Plan," for going 145 days without an onthe-job-injury that required an employee to be confined to home or the hospital. Additionally, for both 1945 AND 1946, the MED won the "Distinguished Award for Safety" of the National Safety Council, a competition that involved over 9,000 companies and agencies. In early 1948, the Atomic Energy Commission (successor of the MED and predecessor of the Department of Energy) reported that, at the Hanford Site, the frequency of disabling injuries among operating personnel was 75 percent below the national average for the non-ferrous metals industry. Furthermore, the construction injury rate for the Hanford Site plants was about 50 percent below the national average.

In December 1948, Atkinson-Jones (A-J), the Hanford Site's construction contractor, reported that its accident record during the past year had been 81 percent lower than the national average, and about ten times better than the construction industry's average, as judged by U.S. Department of Labor statistics. According 




Safety rallies were an important part of life during the original construction of the Hanford Engineer Works, 1944.

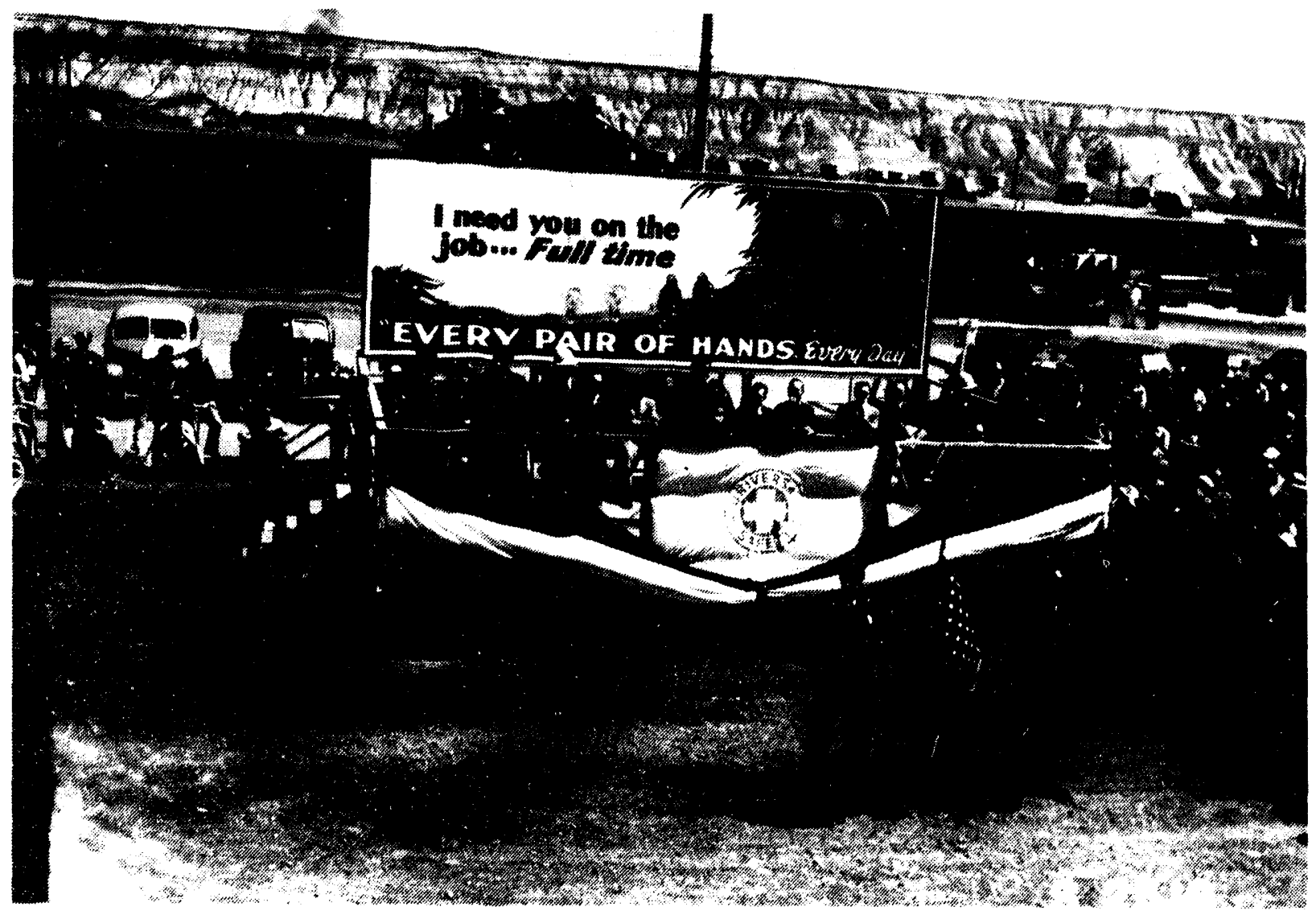


to A-J, this meant that six more workers were alive, 441 more had not sustained disabling injuries, and \$3.5-million in property damage, personal, and hospital costs had been saved, in comparison to what would have been expected if the Hanford Site had conformed to the national average. In January 1949, the winner in a site-wide safety slogan contest for the coming year at the Hanford Site was announced: "For your sake and mine, work safe in '49." This expression soon was printed on all company stationery and emblazoned on posters across the Site.

Likewise, in the government town of Richiand, safe procedures were emphasized constantly. The Richland Villager newspaper and the local radio station, frequently carried articles and programs that instructed residents in safe practices. Also, a Dust and Pollen Control Committee, a Mosquito Control Committee, and a Richland Safety Council were formed. Again, the exhortations worked: in December 1948, the National Safety Council awarded Richland first place among cities under 30,000 people for traffic safety and patrol excellence. In June 1949, Richland celebrated two consecutive years without a traffic fatality, and announced that only three such fatalities had occurred since the government city began to take shape in April 1943.

Two of the safety areas that received special attention were fire prevention and the awareness of fire hazards. The Hanford Engineer Works builders realized that range fires could volatilize contaminated vegetation, thereby spreading airborne contamination. Worse yet, if fire should race across the grass and engulf one of the reactors, fuel fabrication plants, or chemical processing plants, even larger amounts of contamination could be released. According to the DuPont Corporation builders of the Site, "One of the $g$ reatest concerns of the Fire Department was the thousands of acres covered with cheat grass, bunch grass and sagebrush surrounding the plant...A potential fire hazard existed at all times" (DuPont 1946).

The hazards worsened as multiple construction projects got underway and railroad locomotives started many fires along right-of-ways. In August 1943, a program was started to build fire breaks throughout the Hanford Site. Within one year, approximately 1,260 miles of such fire breaks had been dug along roads, rail routes, and telephone and power lines. In early 1944, four Army weapons carriers were converted to grass fire-fighting units, with a 287-gallor water tank and a portable pumping unit mounted on each one. In May alone, 73 grass fires were reported on the Site, and that summer, it was "not unusual" to receive three or more fire alarms within minutes of each other (DuPont 1946). In August 1944, a lookout tower was constructed on Gable Mountain to help in quick fire detection. By that time, a fire station had been established in the 300 Area and in the 100-B Area. Soon afterward, such stations also were established in the 100-D, 100-F, 200-E, and 200-W Areas.

Ironically, one of the ways that Hanford Site builders sought to reduce potential fire hazards was through the use of asbestos, a fact that has created problems for the Hanford Site today. Throughout the first few decades of the Hanford Site's history, when the majority of the buildings were constructed, asbestos 
was considered to be the best fire retardant available, and was the building material of choice in industrial facilities across the nation.

Because of its ability to retain and absorb heat, asbestos was used in the Hanford Site's 100 Areas as a packirig material in the old reactors, and in the 200 Areas around much of the extensive piping networks in the chemical processing buildings and in the 222 Sample Laboratory Buildings. Additionally, in these laboratories and in the 300 Area laboratories, small asbestos sheets were placed beneath hot beakers to cool them, and on top of hot beakers to retain the heat of the liquids inside. Asbestos partitions also were used inside laboratory hoods, and later in glove boxes and hot cells.

The 300 Area fuels preparation buildings, where several furnaces operated, contained much asbestos packing and three-sixteenths-inch asbestos board insulation. Additionally, across the Hanford Site, wherever roofing and building siding was not concrete, it often

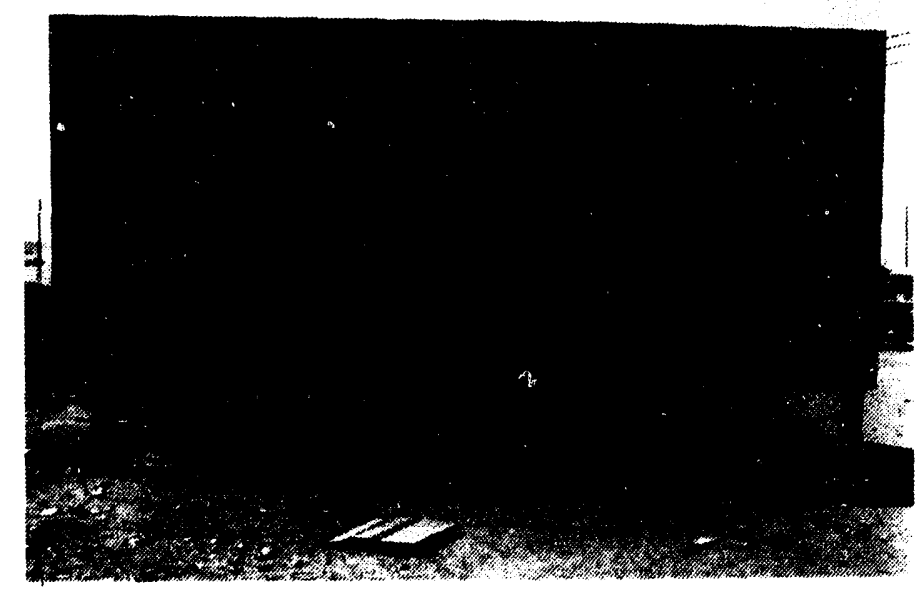

was made of transite -- a manufactured blend of steel and asbestos.

Fire prevention and safety was stressed, not only in Hanford Site operating plants, but in the Hanford Construction Camp that housed 51,000 workers during 1944, and in the government town of Richland. Virtually all of the camp consisted of wood frame, temporary construction structures (known as TC buildings by early workers), as did the Administration Block in Richland, which housed the Hospital, Patrol Headquarters, Military Intelligence, and other key facilities. A special Construction Fire Division was established in the camp, and, by late 1945, Richland contained 101 fire alarm boxes, 451 fire hydrants, and possessed a separate firefighting water supply in two reservoirs of 3,785,400 liters (1-million gallons) each. By 1949, Richland residents had been educated in so many fire safety campaigns and had such an unusually safe record that fire insurance rates were reduced in the village by state and national ratings bureaus.
Safety signs and billboards were a constant reminder of the Hanford Engineer Works' emphasis on safe procedures in its massive building programs. 


\section{Women Have an Important Place in Hanford Site History}

At its peak in 1944, the World War II Hanford Engineer Works employed about 51,000 people. Approximately 4,000 of these were women, or about nine percent of the work force. The great preponderance of men is partially explained by the fact that the majority of Hanford Site workers at that time were construction workers, and women were not included in those jobs.

Most of the Hanford Site's women were secretaries, clerks, nurses, food service workers, barracks employees, and other support service workers, and most

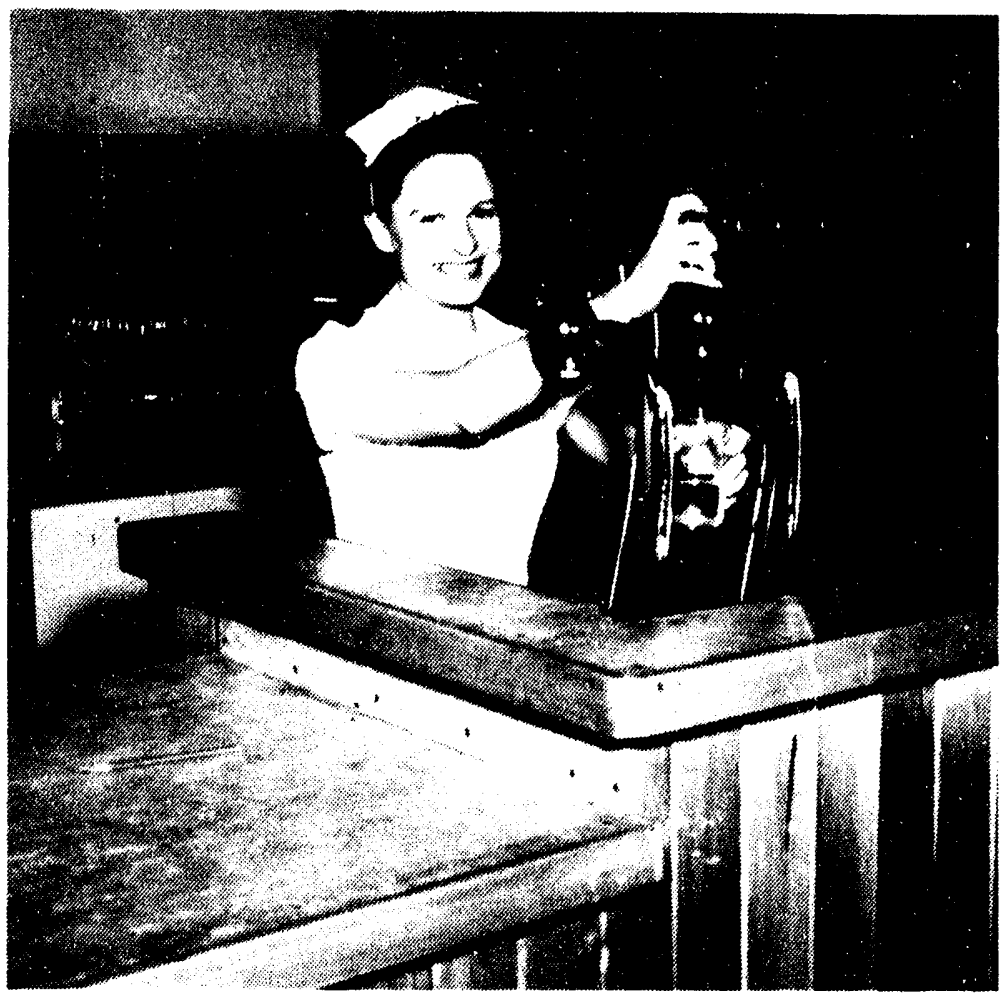

were very young, often on their first adventure away from home. Additionally, a small contingent of the Women's Army Corps (WACs), usually between 16-24 women were stationed at the Hanford Site. Less than one percent of the Hanford Engineer Works managers and supervisors were women, and most of the professional women were nurses. Despite the lack of equal opportunity, Hanford's women came to the remote desert site and served because they felt a personal dedication to the war effort.
A woman employee at one of the many canteens in the Hanford Construction Camp during 1944. 
To ease the shock of transition, and to ensure that someone other than a male Army commander was looking out for the well-eing of these young women, the Hanford Engineer Works took the unprecedented step of hiring a "sort of Dean of Women," (Maris 1960) entitled the Supervisor of Women's Activities. The woman the Hanford Engineer Works hired for this post was Buena Maris, a former Dean of Women at Oregon State College, hired to "promote stability on the urgent (Hanford Site) job," by providing a happy, safe, and constructive atmosphere in which women could work (Maris 1960). She immediately hired a "housemother" for each of the women's barracks in the huge construction camp located at the old Hanford townsite, about 18 miles north of present-day Richland. Mrs. Maris also organized a library, started a Red Cross chapter that still functions in Richland today, and scheduled a special daily bus with a late return to and from Pasco so that women could break the monotony of camp life with evenings out for shopping and dinner. Additionally, she helped the camp Recreation Office plan womens' sports events, parties, and dances, all properly chaperoned of course.

For the married women who had brought families to the Hanford Construction Camp, Buena Maris formed Girl Scouts troops and other children's activities. She was the only woman who regularly attended the staff meetings of the Hanford Engineer Works commander, Colonel Franklin T. Matthias. In the summer of 1944, when Matthias asked her to name the Number One priority grievance of Hanford's women, she replied that the gravel walkways of the construction camp were ruining their tightly rationed shoes. The next morning, she was shocked to see the camp's walkways being paved with asphalt, and she exclaimed in her memoirs about the awesome power of Hanford Site women (Maris 1960).

In addition to the efforts of Buena Maris, the Hanford Engineer Works women, like the men, were assisted by the morale-boosting endeavors of the camp Recreation office. The Recreation staff itself was composed mostly of women, who worked to overcome the turnover problem (which was always 8-20 percent of the work force) caused by loneliness, isolation, the desert dust storms, and a lack of understanding of the Hanford Site's mission. In two weeks in July 1944, a gigantic Auditorium was built in the camp, with entertainment brought in or dances held at least four nights a week. Bingo games, amateur theater performances, and other organized activities filled the other nights.

Another strategy for raising morale among Hanford's women was the "Girl of the Week" contest, where the winner was driven to work in a staff car and honored in other ways. Beauty contests also were a morale booster, and, in the 1940s, were considered a way to honor women. A now-famous Safety Exposition beauty contest was held in the summer of 1944 in order to get Hanford Site men to pay attention to safety and as a way for everyone to break up the monotony and have some fun. Although most of the contestants wore elaborate gowns, the winner was Hope Sloan (now a Kennewick resident) who refused to give up her WAC uniform and appeared in the heavy, plain broadcloth suit. 




Hanford women enjoy a basketball game as part of the Construction Camp's recreation program, December 1944.



The Women's Army Corps contingent at the Hanford Engineer Works on parade in Richland, 1946. 
Sororities also were popular at the Hanford Site Construction Camp, and some of these organizations continued for many years after the war in the government town of Richland. Started in the Depression to help young women acquire "culture" and learn about the arts, some of these non-college affiliated sororities formed chapters at the Hanford Site and held tea parties, book discussions, banquets, and other events.

There were some famous women at the World War II Hanford Site, and there were others who became famous for their accomplishments at the Hanford Engineer Works. Dr. Leona Woods Marshall was a young, Ph.D. physicist who was present at the start-up of B-Reactor and who performed many of the early production test calculations aimed at improving reactor performance. Leona Marshall was honored for her efforts by being chosen among Mademoiselle magazine's "Top 10 Women of 1945" (Mademoiselle 1946). That year, the Hanford Engineer Works achieved a first by becoming the only endeavor to have two women chosen among the magazine's "Top 10;" the other was Hanford's WAC Captain Arlene Scheidenheln.

Jane Jones, a young reporter for the Richland Villager newspaper, started a charitable outreach program from Richland to the war-ravaged European city of Tiel, Holland, after the war ended. This "sister-city" concept soon traveled around the United States and similar programs were implemented in hundreds of cities. In 1946, Carolyn Hageman, wife of a Hanford Engineer Works production manager, wrote the winning essay in Richland's "Win the Peace" contest, a year-long series of events in which the "atomic city" attempted to define its role in building a last:ing, postwar peace. Evoking the innocence of that era, she wrote: "Are our hearts as big as our brains? Are we capable of accepting the responsibility we have thrust on ourselves?... Our problem is how to make nuclear physics contribute to human comfort, human knowledge and hence to human dignity" (Richland Villager 1946).

As the Hanford Site's women moved into the 1970s and 1980s, some important "firsts" were achieved. The Eastern Washington chapter of the Society of Women Engineers was founded in 1976, the first time that the more than 10 female engineers necessary to charter a chapter were employed at the Hanford Site. At nearly the same time, women became. nuclear process operators and reactor operators. In the early 1980s, the first woman "metal handler," (uranium fuel rod fabricator) went to work in the Hanford Site's 333 Building, and the first female construction supervisor at the Hanford Site helped to build the Fuels and Materials Examination Facility (FMEF).

Today, the Hanford Site's statistics look far different from those of World War II. Now, nearly 45 percent of the work force is female, about 15 percent of managers and supervisors are women, and approximately one-quarter of the degreed professionals on the Site are female. And, best of all, they're not known as "girls" anymore. 


\section{The Boom and Bust Cycle: A 50-Year Historical Overview of the Economic Impacts of Hanford Site Operations on the Tri-Cities, Washington}

The coming of the Hanford Engineer Works to the Columbia Basin in 1943 brought unprecedented economic growth. The combined population of Benton and Franklin Counties jumped from approximately 19,000 to nearly 70,000 people in the space of just over one year. Although most of the procurements for the giant Hanford Site construction project came from distant suppliers, taxable retail sales in the two local counties leaped nearly six-fold in three years, from \$5.4-million during 1941-42 to $\$ 32-$ million during 1944-45. However, many economic dislocations accompanied the new prosperity. The wages at the Hanford Engineer Works were considerably higher than what local businesses and farms were accustomed to paying. As a result, farm workers were drawn out of the fields in such numbers that Northwestern Congressmen protested to the War



OFFICER - HOW'S A GUY SDOSED. TO MAKE A LEFT TURN OFF GEORGE WASHINGTON THRU TIIIS 5 OCLOCK TRAFFIC?
A cartoon drawn by Hanford Site engineer Richard Donnell, using the pen name DuPus Boomer, to illustrate the boom effects that engulfed 1940s Richland. 


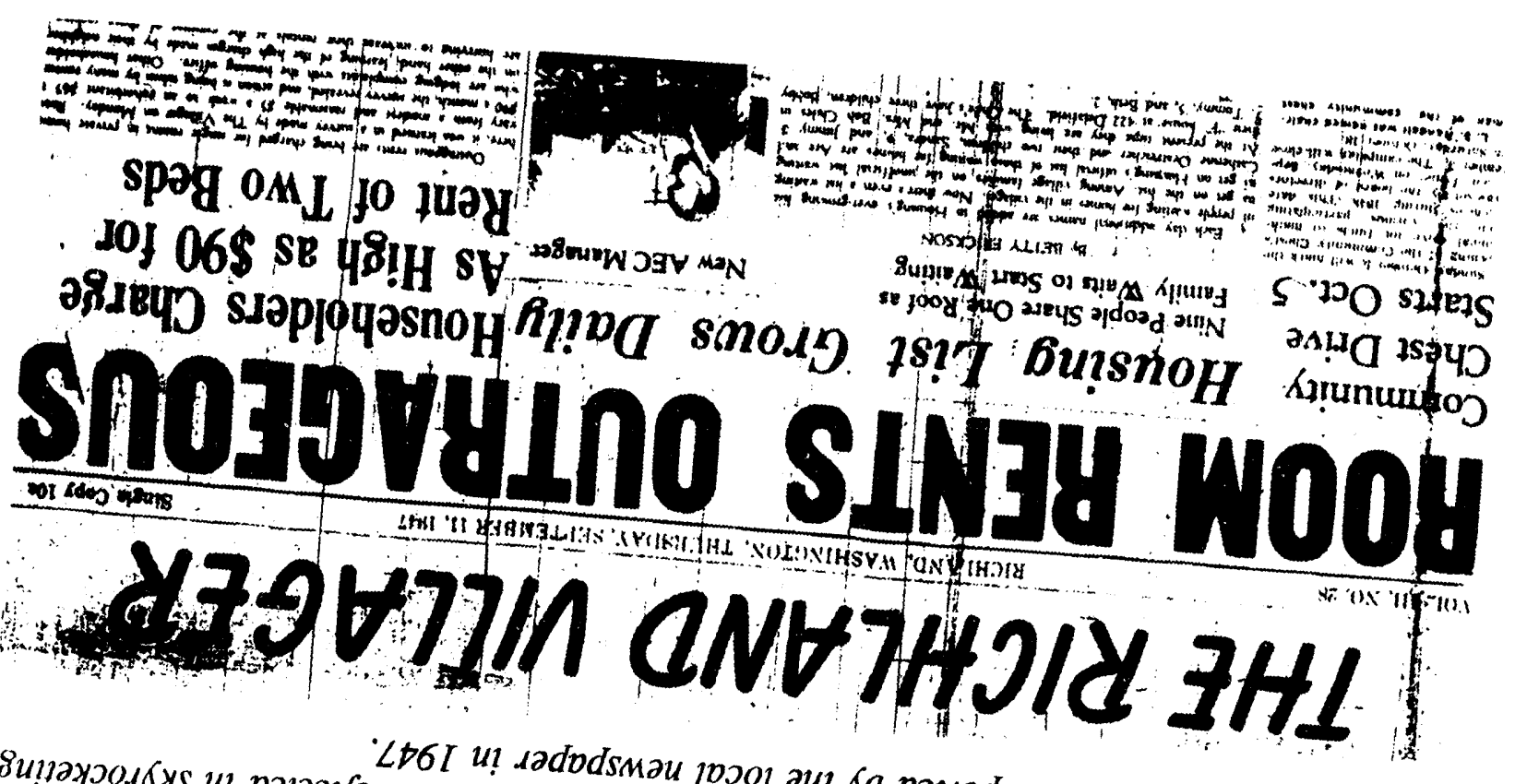

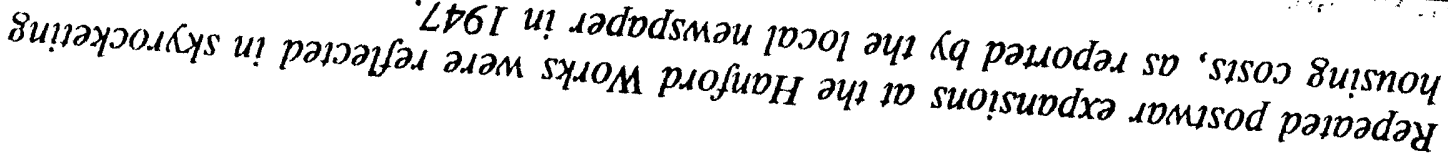

spag OML 10 jüa th

lof 068 sE yolH sV

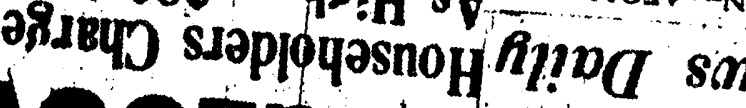

(

729

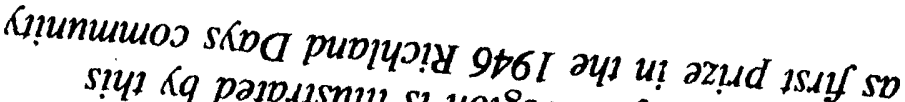

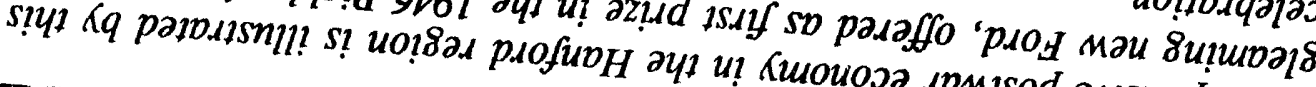

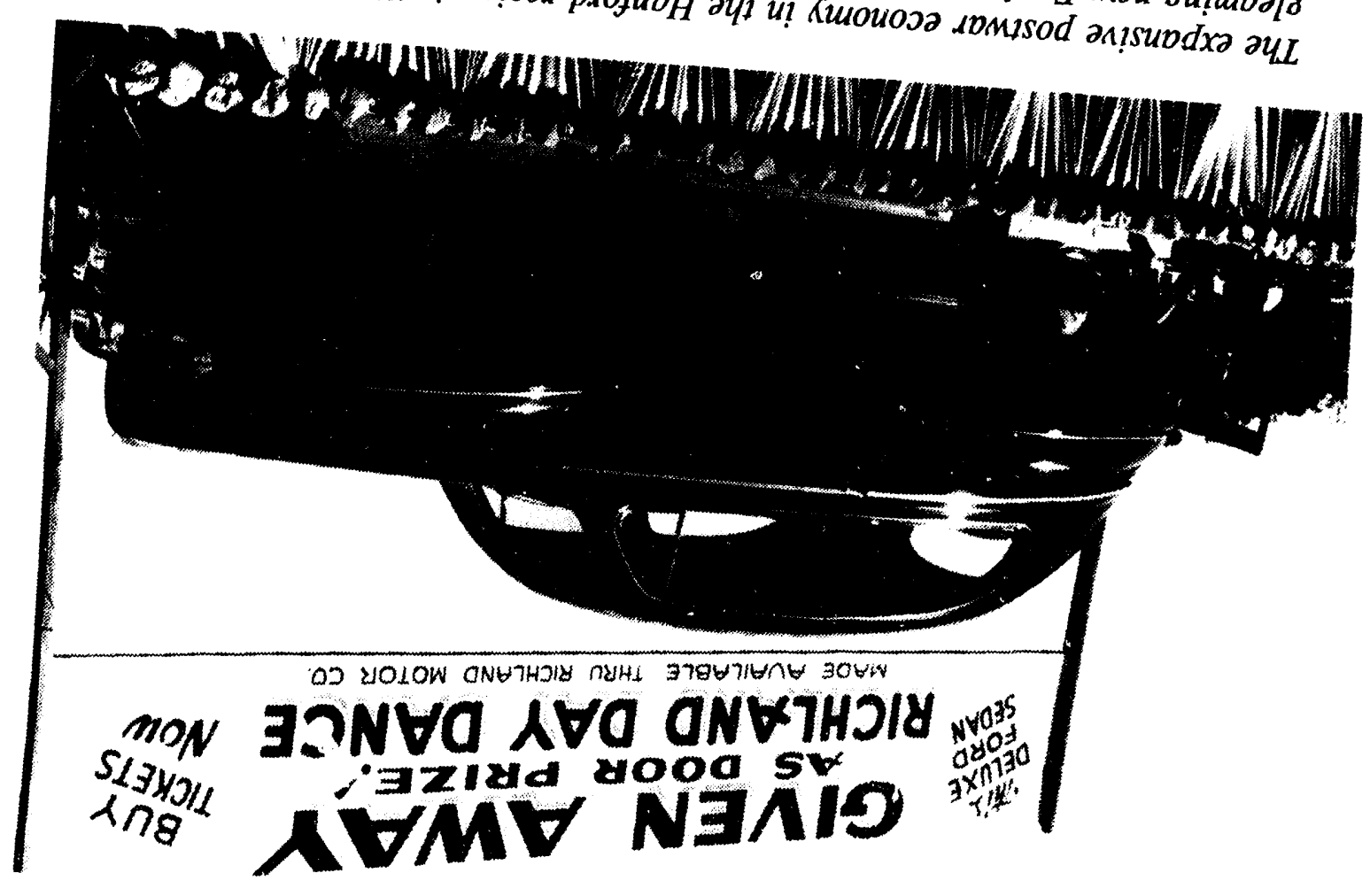


Department that there would be no one left to harvest local crops. Additionally, nearly every town surrounding the Hanford Site experienced shortages in essential services such as school classroom space, hospital beds, recreational facilities, roads, and housing. The Lanham Community Facilities Act of 1941, which was passed to assist war-boom communities in providing these services, could not hope to meet the needs created by the Hanford Engineer Works in the small towns. Also, lands originally planned for inclusion in the Columbia Basin Irrigation Project (CBP) were withdrawn from the project when the Hanford Site was created. According to CBP officials, these losses raised the price of land per acre for the remainder of the project.

The end of World War II, however, brought the region's first Hanford Sitebased recession. While the federal government debated the role atomic energy would play in peacetime America, many of the Hanford Site facilities went to lower power and operating levels. Half of the Hanford Site's operations work force, or 5,000 out of these 10,000 people, left or lost their jobs at the Hanford Engineer Works. Local businesses experienced hard times, and many residents wondered whether the Hanford Site would close altogether. The August 1947 announcement that the new Atomic Energy Commission would expand the Hanford Site with the largest peacetime construction project in American history up to that point, brought renewed prosperity to the region. In the ensuing two years, nearly 10,000 permanent new residents moved to Richland, while a trailer-and-barracks enclave was erected nearby to house approximately 12,000 construction workers and 13,000 of their family members.
Taxable retail sales in Benton and Franklin Counties jumped to $\$ 36.4$-million during 1947-48. Construction of canals and other facilities for the CBP's South District (mostly Franklin County) were delayed because of shortages of workers, materials, and space in Pasco, and the deployment of anti-aircraft defense battalions to permanent stations at the Hanford Site also was postponed because there was no place to house the troops.

The 1947-1949 expansion at Hanford Works (the Atomic Energy Commission's World War II name for the Hanford Site) was followed by two more extensive expansions, filling the years through 1955 with new records in regional prosperity. Additionally, during that period the construction of McNary Dam and the Northern Pacific Railroad's "hump" yard in Pasco further crowded the area with well-paid workers. By 1955, the capital federal investment in Hanford Works alone stood at \$1-billion, and the annual Hanford Site payroll for the 9,000 permanent employees totalled $\$ 55$-million. Boom years continued through the early 1960s in the Hanford region, as the work force remained stable at approximately 9,500 9,800 people. During that period, about 40 percent of Benton's County's total employed labor force worked at Hanford Works, and the annual Hanford Site payroli had climbed to $\$ 62$-million by 1960. Throughout these years, even major facility closures at Hanford Works (such as the closure of T-Plant in 1956) produced virtually no negative economic effects, since the workers were absorbed readily into other Hanford Site jobs.

During the same years, many nonHanford Site jobs and projects, including the construction of five major power 
generation dams along the Snake and Columbia Rivers within 65 miles of the Tri-Cities, fueled the economic boom in the region. In 1961, the Atomic Energy Commission began a policy of encouraging small business growth by awarding 40 percent of its contracts to small subcontractors. Further, the emancipation of the city of Richland from the federal government in 1958 caused housing prices to rise and many new businesses were established. By 1962, the population of Benton and Franklin Counties stood at approximately 100,000 people, 54,000 of whom lived in the Tri-Cities.

The local economic picture changed considerably in the mid-1960s, when President Lyndon Johnson announced that the Hanford Site's reactors, as well as the REDOX facility, would begin to close. By late 1966, the Hanford Site work force had dropped to 7,500, and in 1971 it fell to 6,900 people - the lowest number since early 1947. Anticipating this development, a group of local business people formed the Tri-Cities Nuclear Industrial Council (TRICNIC - predecessor of today's TRIDEC) in 1963, to help diversify the economy. TRICNIC encouraged the Atomic Energy Commission to negotiate unique contracts, requiring the creation of "spin-off" local businesses and contributions to the Joint Center for Graduate Studies, with new companies coming to operate portions of the Hanford Site. Many of the new contractors responded, including Douglas United Nuclear, which built a medical laboratory and a private zirconium tube manufacturing facility; Atlantic Richfield Hanford Company, which constructed the Hanford House Hotel and a beef packing plant; and many others. By the end of 1971 , over $\$ 40$-million in new private capital had been invested locally, and the Atomic Energy Commission pointed to the Hanford Site's diversification program as a model for the nation.

In the meantime, business development went forward both on and off the Hanford Site. The contract to build the Fast Flux Test Facility (FFTF) was secured in 1967, and the Washington Public Power Supply System (WPPSS) signed in 1971 to construct the first of five commercial nuclear power plants (three on the Hanford Sitc) in 1971. In 1964 and 1966, Richland purchased over 400 acres of land on the north edge of the city and developed the neighborhoods around Saint and Snyder Streets and Spengler Road. The city also purchased 6,000 acres at the Horn Rapids Triangle in 1967, and annexed Meadow Springs in 1971. Much private local construction also took place, including the building of the Pasco Red Lion Motel, the Rivershore Inn, Western Sintering Corporation, a new Kadlec Hospital, and other projects. Overall, the regional economic situation stabilized, but with slightly less dependence on federal jobs at Hanford, and the two-county population remained at about 100,000.

A large regional boom began in the early 1970 s, as ground was broken for the three WPPSS reactors on the Hanford Site in 1972, 1975, and 1978. Additionally, the Basalt Waste Isolation project (BWIP), an endeavor to characterize a potential site for a national nuclear waste repository at the Hanford Site, brought jobs, as did the construction of 17 of the Hanford Site's 28 double-shell waste tanks between 1968 and 1981. Signs of the boom were clear: construction permits issued in the Tri-Cities totalled \$36-million in 1973, and rose by 71 percent to $\$ 63.2$-million in the 
next year. Retail sales in Benton and Franklin Counties rose by 35 percent in 1974 alone, reaching $\$ 460$-million that year.

A severe downturn in the local economy began in 1982, with the completion of FFTF construction, and the stoppage of work on two of the WPPSS reactors. The completion of the third WPPSS reactor in 1974, as well as the closure of the BWIP program and $\mathrm{N}$-Reactor in 1987 further constricted employment. Hanford Site employment (non-WPPSS) immediately fell from 15,400 in early 1987 to 10,700 in 1989 , and the Hanford Site's budget likewise turned downward. Housing starts and housing sale prices declined, while housing and retail vacancies, along with bankruptcies rose. Most recently, the entire cycle has changed again, as the Hanford Site's waste cleanup mission began to enlarge the Site's budget in 1990. Today, over 16,000 people are employed at the Hanford Site, and the Site's payroll comprises about 42 percent of the total payroll for Benton and Franklin Counties. With more than \$1.4-billion budgeted for the Hanford Site this year, Hanford Site leaders predict that the boom is temporary and that diversification is the key to the region's economic future.

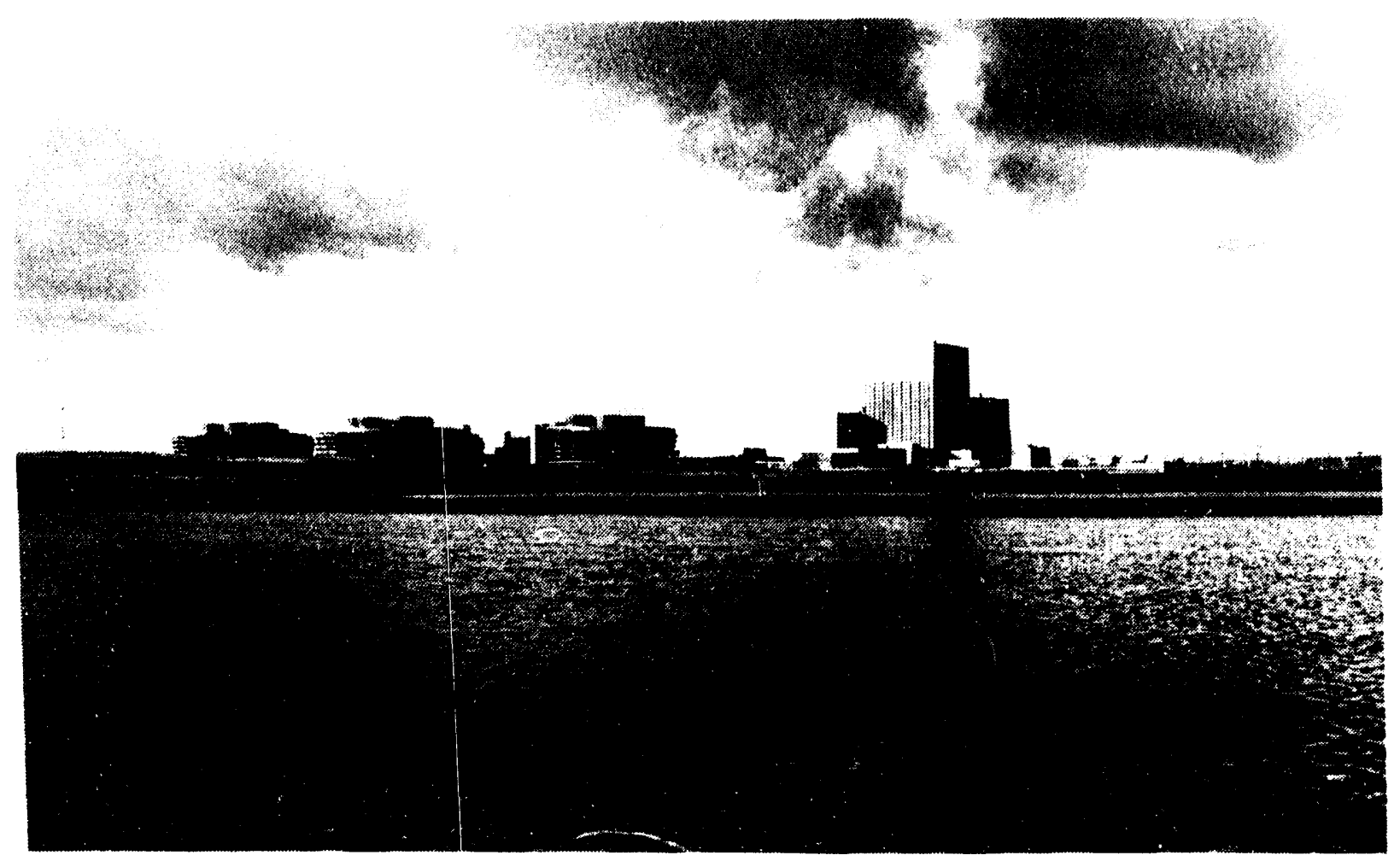

Construction of three Washington Public Power supply System reactors on the Hanford Site during the 1970s brought the largest economic boom that had been experienced in the region since World War II. Reactor No. 2, shown here, was the only one to be finished and to become operational. 

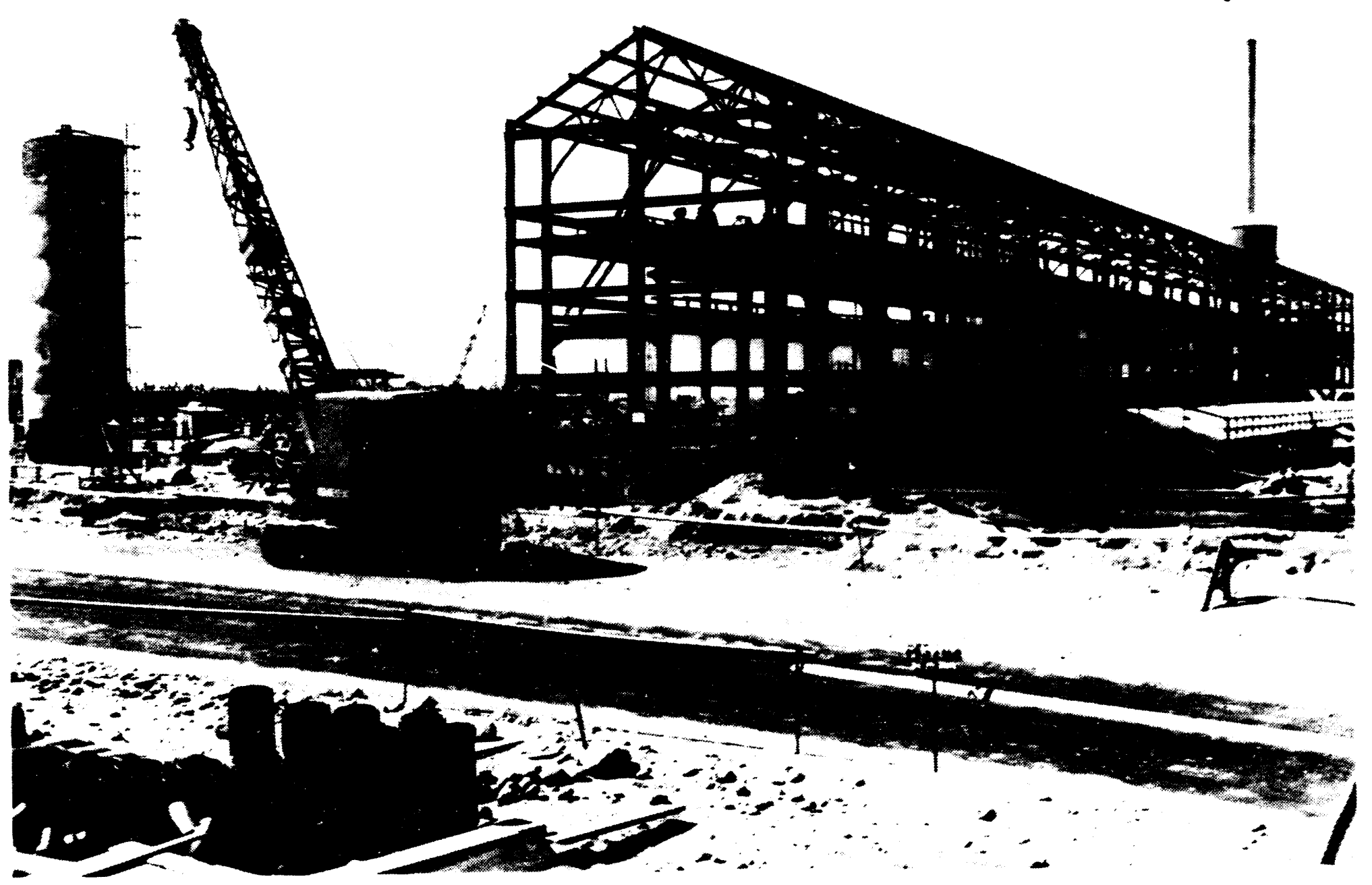

The 183-D Filter Plant and Chemical Treatment Building, a crucial support facility to the water influent system of DReactor, under construction in 1944. 


\section{Hanford's Early Reactors Were Crucial to the Site's History}

The eight oldest reactors (not counting N-Reactor) that stand as monoliths on the shoreline of the Hanford Reach contain stories that are among the richest in nuclear history in the world. Now silent, these reactors once hummed with the roar of water rushing through their process tubes and achieved the greatest throughput of special nuclear materials of any place known on earth. With an average individual life span of just 22 years, these eight reactors, which were known as "piles" during the 1940s and 1950s, were built between 1944 and 1955, and closed down between 1964 and 1971.

Tied in umbilical fashion to the Columbia River, the eight old reactors were known as "single-pass" facilities because their cooling systems drew water from the river, treated it chemically, pumped it through the process tubes to cool the uranium fuel charges, and then passed the water out to the river again for disposal. Between the reactors and the return trip to the river, the used cooling water (effluent) was held in large tanks known as 107 Retention Basins for periods that ranged from 30 minutes to 6 hours. This temporary retention provided for the decay of short-lived radionuclides picked up in the reactors. However, the longerlived isotopes were not affected by this retention period, and thousands of curies entered the Columbia River every day, provoking, by the early 1960 s, protests from the health departments of Oregon and Washington, as well as the U.S. Public Health Service.
At the World War II Hanford Site, the historic feat of starting up the first three, full-scale nuclear reactors in the world within a period of five months ushered in a 27-year period of hectic and remarkable pile development. The World War II reactors (B, D, and F) each were designed to operate at 250 megawatts (MW) of nuclear power. H-Pile, which started up in 1949, was designed to operate at $400 \mathrm{MW}$, and DR (D-Replacement), which started up in 1950 , was a clone of D-Pile, designed to operate at $250 \mathrm{MW}$. C-Reactor, which was started up in 1952 with a nameplate design power level of $600 \mathrm{MW}$, soon became the chief developmental and production testing machine at the Hanford Site. Within three months of its startup, its primary function had been designated as that of prototype experimentation for the design of the "twin" K-Piles (KE and $\mathrm{KW}$ ).

Completed in 1955, the KE and KW reactors were known as the "jumbos," because their nameplate design power levels stood at $1,800 \mathrm{MW}$, more than seven times larger than those of the World War II reactors. By the early 1960s, extensive modifications and upgrades had allowed the oldest five piles to achieve power levels ranging from 2,015 to 2,210 MW each, C-Reactor to attain 2,500 MW, and the K-Piles to reach 4,400 MW each. Thus, the scale-up achieved during the operating years was nearly as great as the historic leaps attained in World War II while building 


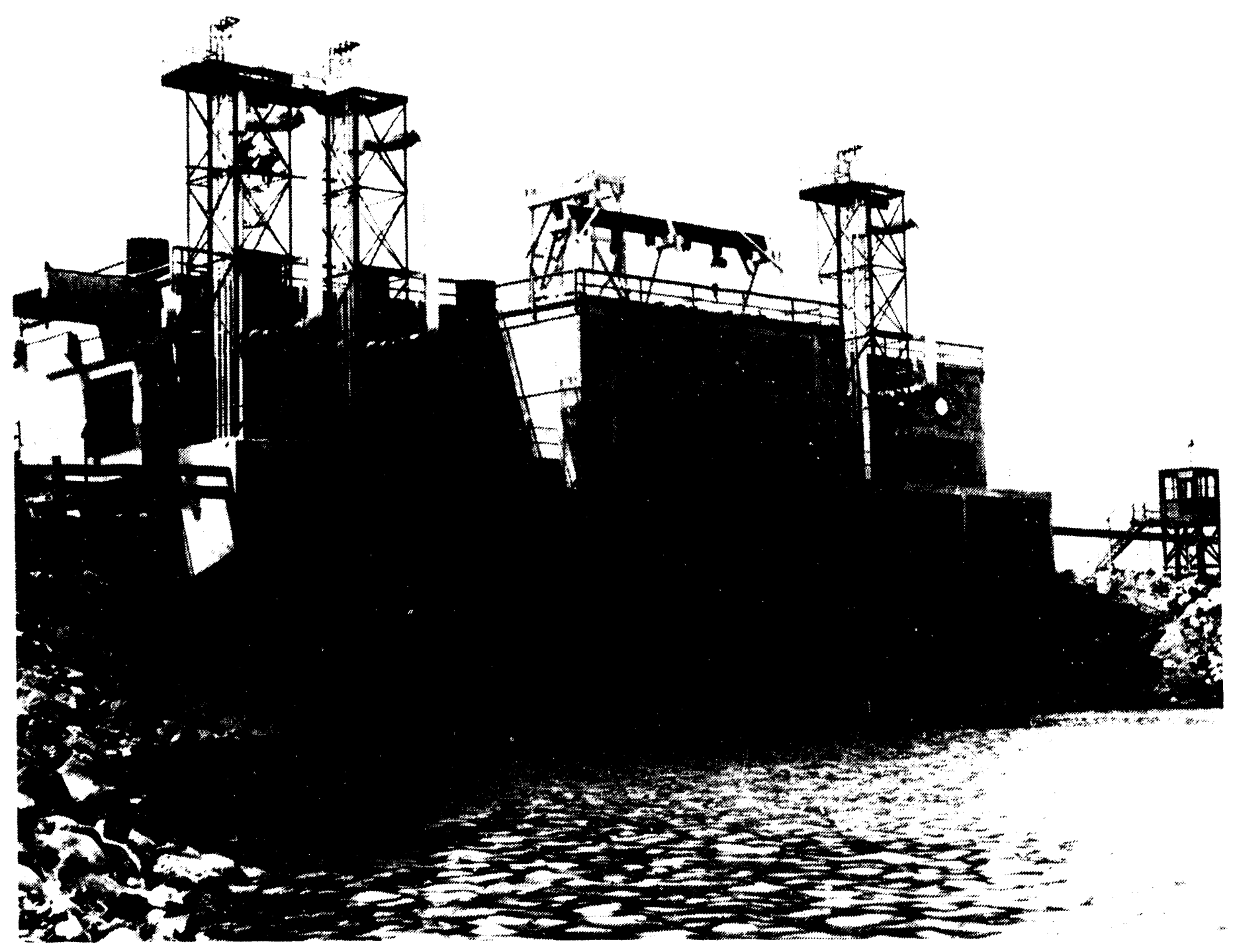

A late 1940s view of the 181-B River Pump House, which removed water from the Columbia River to cool B-Reactor, the world's first, full-scale, nuclear reactor. 
the original Hanford Site plants from laboratory-sized prototypes. And, along the way, some of the most important discoveries in physics and irradiation science were made.

The early operators of the Hanford Site's piles were puzzled and intrigued by many questions. For example, they knew that "slug failures," or the accidental penetration of a uranium fuel element's aluminum jacket (can) by cooling water, would cause the uranium to swell and block the coolant flow within the process tube and melt the slugs within that tube. No slug failures occurred at the World War II Hanford Site, but by December 1945, 125 slugs with mysterious "blisters" had been found by visual inspection in the irradiated fuel storage basins at the lear of the three reactors. Operators developed a pneumatic underwater lathe for opening up the warped slugs for further examination. For the next 7 years, blistered and ruptured fuel elements were opened and examined in steel tanks located in the 111-B Test Building. After the 327 Radiometallurgy Facility was ready, with its state-of-the-art hot cells, the 111-B Building continued to be used as an examination facility for sections of corroded and failed process tubes.

When fuel ruptures did occur, Hanford Site operators detected the problem with beta-sensitive water activity monitors located in the rear piping of the reactors. Higher radioactivity levels indicated a rupture, and the process tube containing the failure simply was emptied into the irradiated fuel storage basin.

Sometimes, however, ruptures were severe enough that the failed elements stuck in the process tubes, and Hanford Site operators had to invent completely new techniques for removing the slugs and the tubes. They first flushed out the charges located downstream of the failed element (ie., in "back" of the problem slug in the process tube), and then removed the upstream charges using vacuum suction. They next employed a rotary reamer to bore out the tube ribs (internal projections used to guide and seat the fuel elements) downstream of the problem. The stuck charge then was pushed downstream with a hydraulic ram until it entered the de-ribbed area, where removal was completed with force from the pneumatic slug charging machine. Next, the damaged process tube was split internally with a special tube splitter developed at the Site, and then pulled out and chopped into short lengths with a unique Hanford Site instrument known as the "guillotine."

Another topic that intrigued the early operators of the Hanford Site's piles was that of temperature and flux distribution (flux is a measure of the number and speed of neutrons that are active at various nuclear power levels). During startups, flux levels cinanged rapidly as the control rods were withdrawn, and sometimes quirky and localized hot spots (areas of very high neutron activity) occurred. Such events could damage parts of the reactors, or cause automatic shutdowns triggered by safety instrumentation (known as instrument scrams). A distinct learning curve with regard to managing smooth startups separated junior and senior reactor operators.

Even after full operating power was achieved during the earliest years, a uniform poison (neutron absorbing) pattern was used throughout the reactors. This resulted in a flux distribution that achieved maximum irradiation only for the fuel 
charges located in the center of the piles, a situation that was inefficient in using the uranium fuel supply. Therefore, experimentation with varied poison patterns was undertaken, and, as with other operations, Hanford Site workers developed a colorful array of names for the different patterns: "dimpling," "bowing," and "thinning" the piles were among the flux distribution patterns of the late 1940s.

None of the early operating questions were more serious to Hanford Site scientists than that of graphite distortion. By early 1946, expansion of the graphite reactor cores, with subsequent bowing and binding of process tubes, had become so serious that B-Reactor was shut down to preserve it while graphite study went forward. The problem, as it turned cut, was caused by the efficient heatremoval capacity of the helium in pile gas atmosphere. Higher temperatures were needed to activate and redistribute the carbon atoms in the graphite's crystal lattice. By the late 1940s, the addition of carbon dioxide, with its lower heat-transfer capacity, to the gas atmospheres of the Hanford piles annealed and aided the graphite expansion situation.
During the 25 years that followed the energizing of the first Hanford Site production reactor, many other puzzles were solved. In the constant search for operating efficiencies that would boost production, machines were developed that could charge and discharge a reactor while it was operating. Other new procedures cleansed film from reactor tubes during operation, and equipment known as "poison splines" allowed multiple modifications in flux and heat distribution as a reactor ran. New configurations and materials in fuel elements and process tubes allowed power levels nearly ten times those of the World War II era. However, while technical operating challenges progressed well in these historic reactors, waste disposal solutions remained elusive, and effluents continued to be released to the Columbia River. 


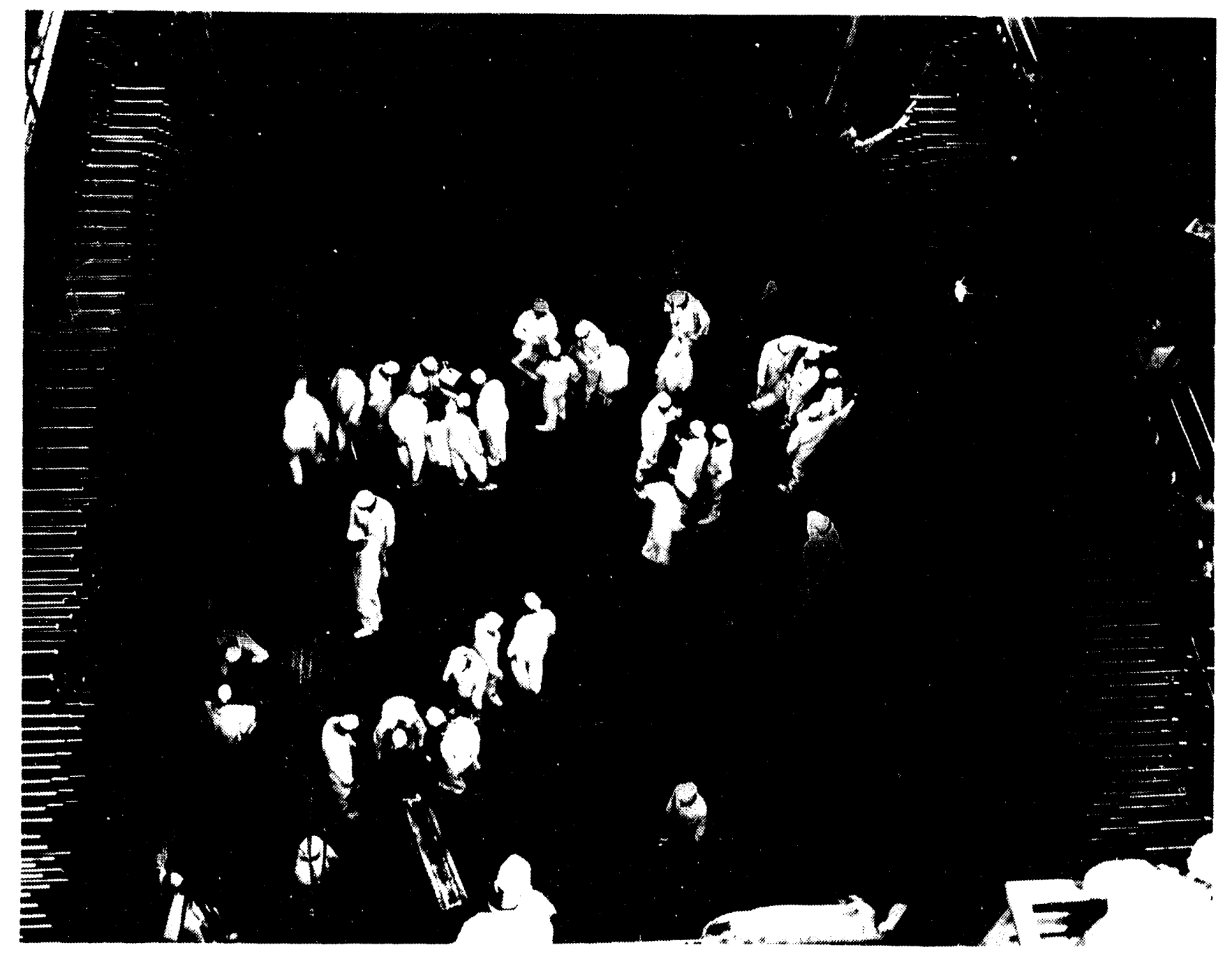

Hanford Site workers lay up the graphite for C-Reactor, the Hanford Site's sixth production reactor, in early 1952. 


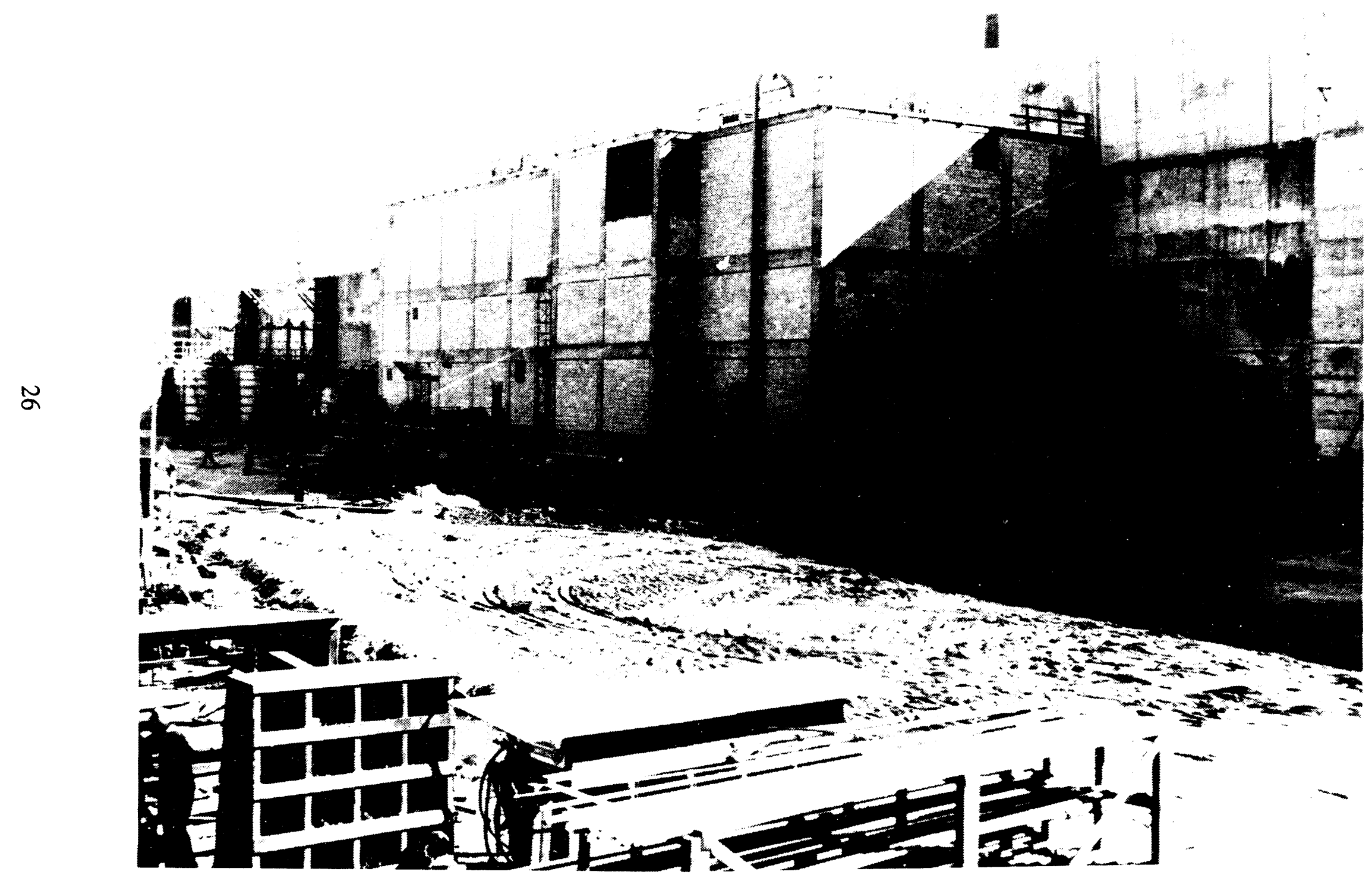




\section{T-Plant Made Chemical Engineering History}

T-Plant (221-T) was the first and largest of the early chemical separations plants at the Hanford Site. Officially designated as a Cell Building by the DuPont Corporation builders of the Hanford Engineer Works, T-Plant separated the plutonium from B-Reactor's earliest irradiated fuel, and served as the headquarters of chemical processing operations at the Hanford Site throughout the $1940 \mathrm{~s}$. Because it formed a crucial link in the first, full-scale plutonium production operations in world history, it may meet criteria established in the National Historic Preservation Act of 1966 as a National Historic Structure.

\section{Construction:}

Ground was broken for T-Plant (also known as T-canyon) on June 22, 1943, with the original finish date set for "30 days after the completion of 100-B" Area (DuPont 1945a). However, construction proceeded slowly throughout 1943 , as higher priorities were assigned to the construction of B-Reactor, fuel fabrication facilities in the 300 Area, and additional living quarters in the Hanford Construction Camp (By 1944, this camp, located at the old Hanford townsite, housed 51,000 people).

Aggregate for the concrete used in the construction of T-Plant was supplied from the Haven Barrow Pit, located approximately one-half mile west of the 100-B Area; from the Hanford Barrow Pit, located about one mile west of the old
Hanford townsite; from a barrow pit dug on the site of the future 288-W Ash Disposal Basin; and from the excavations for the 221-T and 221-U Buildings themselves. A batch plant for mixing and pouring the concrete used in T-Plant was built near the huge canyon, but was disassembled and moved to the 200-East Area in June 1944, after 90 percent of the concrete had been poured for T-Plant.

In December 1943, a special, 65-foot long, "Head End Addition" was authorized for T-Plant in order to house laboratory equipment for radiochemical process improvement tests for the bismuth phosphate separations process used at the Hanford Site. This addition made the plant the largest structure at the Hanford Site. At midnight on October 8, 1944, all construction forces were removed from T-Plant. Chemical runs, practice runs using cold (unirradiated) slugs, flushings, and calibration tests were made during November and early December. The first batch of irradiated fuel rods from

B-Reactor was processed on December 26 and 27, 1944.

\section{Plant Layout:}

T-Plant contained 42 concrete process cells, arranged in 21 pairs (called sections) along the length of the building. Five pairs of spare cells were built in because, according to DuPont, "At the time design was begun, the [separations] process was largely undeveloped. This required the incorporation of sufficient 
flexibility to permit minor changes and also fundamental alterations in the equipment arrangement and process flow" (HEW 1945). The head-end cells contained 14 sets of test equipment, scaled down to $1 / 20$ th of plant size. T-Plant also contained three galleries that ran the length of the facility: the pipe gallery on the first floor, the operating gallery above that, and the electrical gallery in the basement.

A 75-ton overhead crane ran the length of the facility.

\section{Original Separations Process Used Bismuth Phosphate:}

Early T-Plant used a bismuthphosphate (BiPO4) chemical separations method -- a batch precipitation process that achieved separation by varying the valent state of the Plutonium-239, and then repeatedly dissolving and centrifuging plutonium-bearing solutions. It was based on the fact that bismuth phosphate is similar in crystal structure to plutonium phosphate. By precipitating bismuth phosphate, the Plutonium-239 in the tetravalent state could be carried with it. In the hexavalent state, the Plutonium-239 would not carry with the bismuth phosphate, and a by-product precipitation could be achieved.

The first step in the BiPO4 separations process was dissolving, a process that used nitric acid to remove the aluminum fuel jackets from irradiated uranium elements. The second step was extraction, wherein Plutonium-239 was separated from most of the uranium, and about 90 percent of the fission products were removed into what was called the metal waste solution. The third step, decontamination, was carried out in two cycles, with a final "decontamination factor" (reduction in gamma activity level from the original metal solution) of 100,000 obtained in the overall process. Following all of the cycles in T-Plant, plutonium bearing solutions were sent in 300-gallon batches to the 224-T Bulk Reduction Building for further processing, and then to the $231-\mathrm{Z}$ Isolation Building for purification into the final Hanford Engineer Works product, a Plutonium nitrate paste.

\section{Early Process Improvements:}

T-Plant and the other Hanford Site separations canyons were designed on the basis that one plant would have the capacity to process the output from one pile (reactor), or about one metric ton of metal (containing approximately 250 grams of Pu-239) every day. However, by the summer of 1945, batch size had been increased to 1.5 metric tons of metal, and by September 1, process modifications enabled the plant to complete the processing of a batch in just 20 hours.

Other early changes focused on simplifying operations to achieve reductions in process time, modifying the process to increase canyon capacity per batch (while stiil preventing "product accumulation"), reducing waste volumes and the amount of fresh chemicals used for every unit of production, recovering additional product from wastes, establishing better understandings of process safety, improving decontamination, and studying the basic chemistry of plutonium. 
4.



T-Plant as it stood new in early 1945.

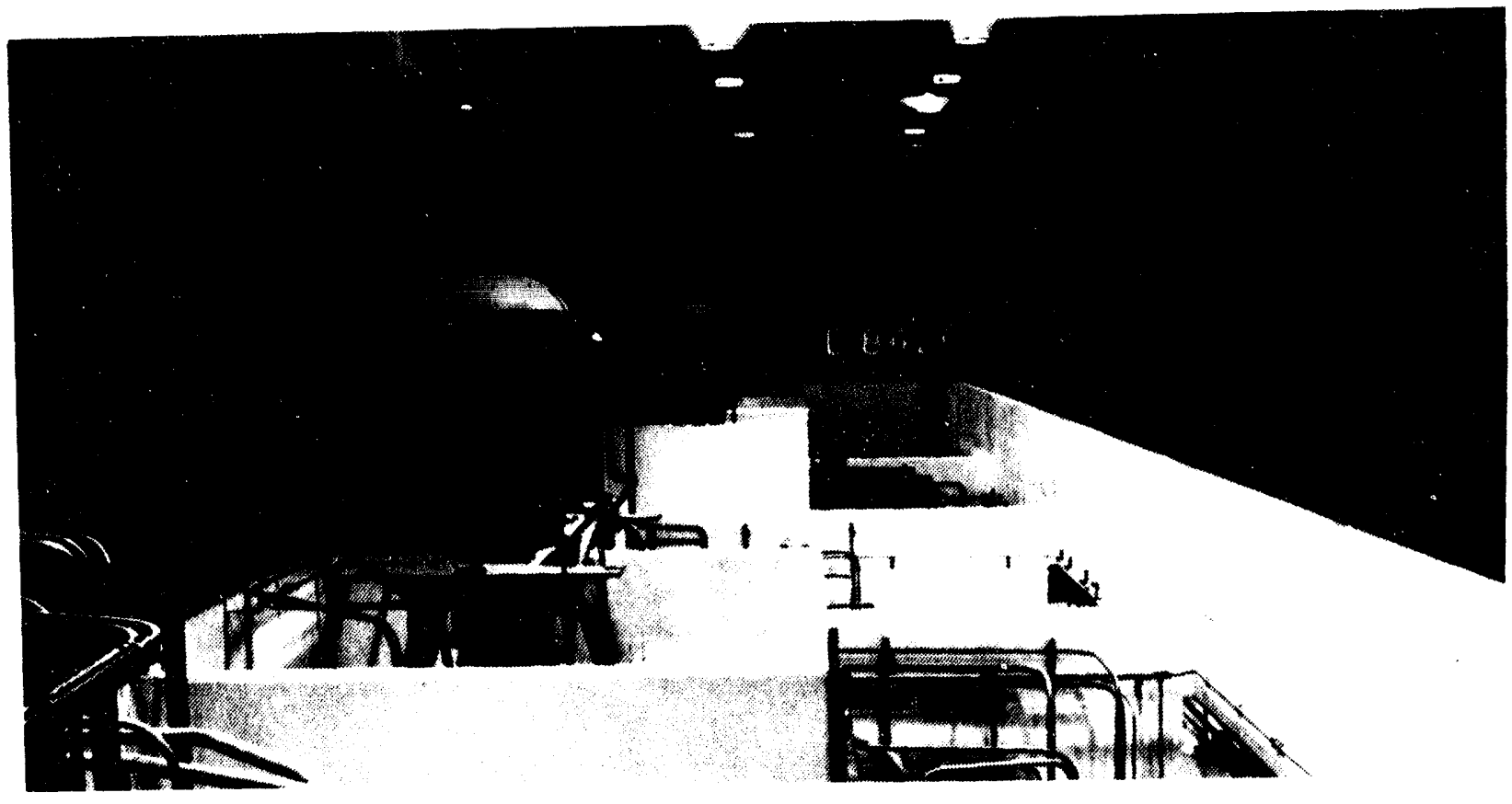

Interior view of T-Plant's Pipe Gallery during World War II. 


\section{Atmospheric Releases Were an Early Worry:}

Releases of gaseous fission products, primarily radioiodine and radioxenon, from chemical processing operations, were an early concern of Hanford Engineer Works planners and builders. According to DuPont, "these potentially serious conditions demanded that all such...by-products be disposed of safely. The means chosen consist of high [200-foot] ventilation stacks and fans which discharge the gaseous by-products to the atmosphere well above ground level" (DuPont 1945b). A meteorology program also was established in order to "schedule dissolver operations when atmospheric conditions are conducive to maximum dispersion." However, T-Plant and B-Plant (the other active Hanford Engineer works processing canyon) did continue to release gaseous fission products in significant quantities until silver nitrate filters were installed in late 1950.

\section{Chemical Processing Continued Until 1956:}

Throughout the 1940s, the efficiency of the bismuth phosphate process continued to improve at T- and B-Plants. By 1950, the Hanford Engineer Works Plutonium-239 production rate had increased to 299 percent of the 1946 rate. Research and development had cut the processing time cycle by 45 percent, and also decreased the amount of fresh chemical materials needed. Plutonium production at Hanford Engineer Works continued to increase in 1951 and 1952, when the rate stood at five times that of 1947.

However, the importance of T-Plant diminished somewhat with the startup of the REDOX (reduction oxidation) chemical processing plant in January 1952. The new plant was much more efficient in that it operated with continuous action, solventextraction chemistry and it salvaged most of the uranium that was not converted to plutonium. In 1953, overall Hanford Engineer Works plutonium production rose by 38 percent over that of 1952 , with 88 percent of the processing conducted in the REDOX Plant. T-Plant accounted for the remaining 12 percent, since B-Plant had shut down shortly after the REDOX Plant began operations.

Plutonium production continued its dramatic rise at the Hanford Site throughout the 1950s. Likewise, T-Plant operations were characterized by increased time cycle efficiency to the point where the processing time cycle dropped to 4.5 hours in 1955. By 1956, however, the great processing efficiencies being experienced at the REDOX Plant and at the new PUREX (plutonium uranium extraction) Plant made the operations of T-Plant unnecessary. In March of 1956, it was retired from active service as a chemical processing facility. The following year, it was retrofitted as the Hanford Site's decontamination facility. 


\section{The $\mathrm{UO}_{3}$ Plant Has a Long History of Service}

\section{WORLD WAR II BEGINNINGS}

The original Uranium Trioxide $\left(\mathrm{UO}_{3}\right)$ Plant was located in a World War II facility known as the 2? 4-U Bulk Reduction Building. This three-story, frame and concrete block structure was constructed to house a part of the plutonium separation and concentration process used at the Hanford Site in the 1940s. However, process improvements as early as 1945 demonstrated that the 224-U Building was not needed. Rather than contaminate it with plutonium, Hanford management decided to use the building as a training facility until another use was found.

The basic $\mathrm{UO}_{3}$ process, calcining, consisted of concentrating and then heating liquid uranium nitrate hexahydrate (UNH the uranium product stream that resulted from certain solvent extraction processes) until it converted to a stable, orangeyellow powder. The nitric acid in the UNH solution also could be recovered in the same process. The $\mathrm{UO}_{3}$ powder was the base material needed for the manufacture of uranium hexafluoride (UF6), the primary feed material for the United States' gaseous diffusion plants. Since the largest of these plants were located far away in Ohio and Tennessee, it was considered safer to ship the material across the country in powder form than in liquid form. It was not possible to operate the $\mathrm{UO}_{3}$ process at the Hanford Site until a feed supply of UNH became available in 1952, with the startup of the REDOX
Plant and the Metal Recovery Plant (U-Plant, also known as the TBP Plant during the Metal Recovery Mission). The earlier separations process used at B- and T-Plants had lost the incoming uranium as waste. But the newer solvent extraction processes used at REDOX and U-Plant recovered the incoming uranium as a complexed salt (UNH).

\section{EARLY OPERATING DIFFICULTIES OVERCOME}

The $\mathrm{UO}_{3}$ Plant began test runs in January 1952, and full operations the following month. Thus, a full cycle of uranium into and out of the Hanford Site was completed for the first time. The first $\mathrm{UO}_{3}$ calciners were simply large pots that heated the UNH in batches. Early difficulties concerned the UNH feed from both REDOX and the TBP Plant, which contained metallic impurities and nitric acid concentrations high enough to make much of Hanford's $\mathrm{UO}_{3}$ product inadequate for successful processing in the continuous UF6 conversion process at the Oak Ridge National Laboratory (ORNL). In addition, the TBP Plant UNH foamed, caked, and stuck in the pots during the calcining process because of the presence of organic decomposition products, so that the $\mathrm{UO}_{3}$ Plant had to be vacuumed and even chopped out. This condition was undesirable from the standpoints of efficiency, operator safety, and contamination control. During 1952-1953, process improvements extending back into the REDOX and TBP Plants were made in 
an effort to correct these situations. By the end of 1953, the UNH was so pure that the $\mathrm{UO}_{3}$ Plant product was able to be shipped and used directly at the ORNL. That year, the $\mathrm{UO}_{3}$ Plant reached the point that it processed more than 1.5 times the total amount of uranium that was received at Hanford.

During 1954, $\mathrm{UO}_{3}$ Plant capacity increased to 18 tons per day, with the addition of two gas-fired calciners. The unit cost for every ton also dropped to 79 percent of the cost in 1953. Several problems were encountered and overcome during 1954, including high radiation fields around the calciner pots caused by the processing of newer UNH (higher in isotopes of zirconium, niobium, and ruthenium) from the two Hanford Site feed plants. This problem was solved by the addition of special shielding to protect operators during pot unloading. Also, sulfamic acid added to the UNH before calcination caused some caking in the

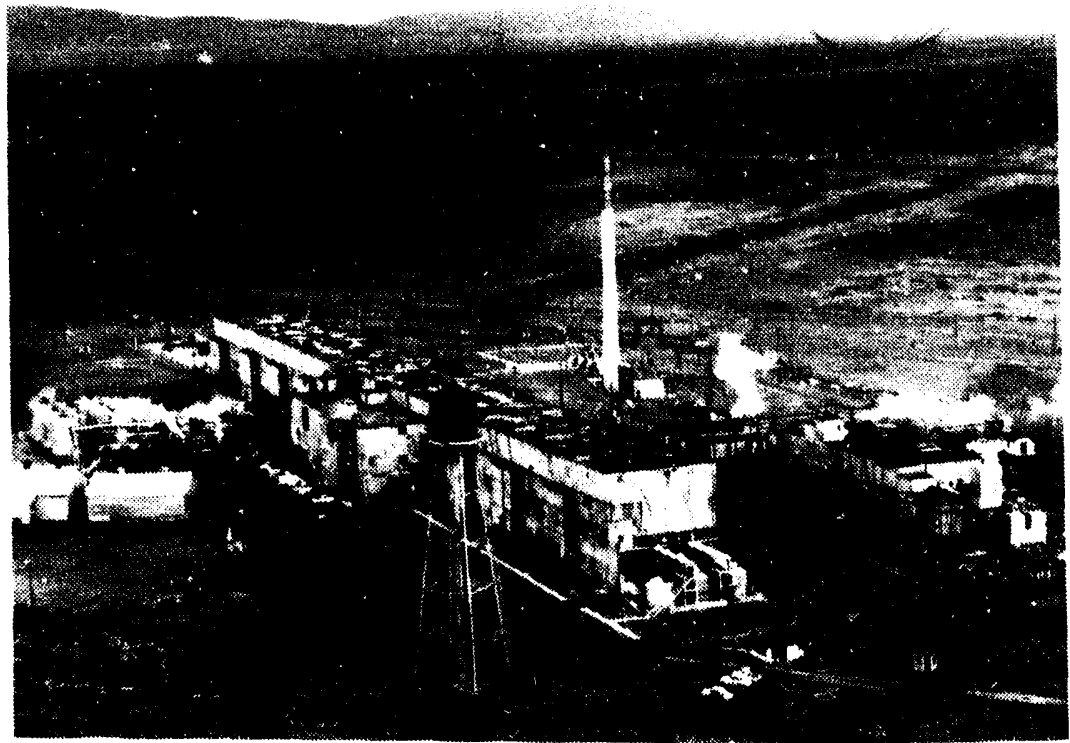

calciner pots, and renewed foaming occurred because of the presence of organic decomposition products. Silicon anti-foaming agents, as well as other sulfur-based additives, were used to control these situations. Another key improvement that year was the use of vacuum cleaning techniques that enabled the plant to recover $90-95$ percent of the oxide powder associated with failed filter bags. A large backlog of such bags, which had accumulated since startup, was cleaned and discarded.

During 1955, monthly $\mathrm{UO}_{3}$ production averaged 106 percent that of 1954, while the unit costs per ton dropped to 92 percent those of the previous year. However, problems resulted from the gradual corrosion and mechanical wear of equipment of calciner seals and gaskets to the point where a vacuum could not be maintained in the pots. Airborne
The 224-U Building, functioning as the $\mathrm{UO}_{3}$ Plant, is the smaller building to the right of the giant U-Plant, as seen in 1953. 
contamination around the pots increased until operators had to wear assault masks. In 1956, equipment modifications, including new pot agitators, shafts, seals, bearings, and supports, as well as new pot cover assemblies, off-gas systems, and gaskets, were installed to address these problems.

\section{EXPANSION TO 224-UA}

In the meantime, workers went forward with plans to construct the 224-UA Building, a major addition to the $\mathrm{UO}_{3}$ Plant, which was to be equipped with six large, new, continuous action calciners. These calciners were developed and designed at Hanford, and had large troughs with paddle agitators that essentially turned and mixed the UNH throughout the process. The caking and clogging problems that had plagued the pots were obviated by the valving of the continuous calciners, which used air as an agitant and maintained a seal between the calciner and the powder pickup bin. The new calciners also produced a pebbly product that consisted of spheres with an average diameter of 200 microns [about .025 centimeters (1/100th of an inch)], as opposed to the granular oxide product of the pots. The first three of the continuous calciners began operations in the last quarter of 1956, and, despite early mechanical difficulties, they soon demonstrated their production potential. That December, $\mathrm{UO}_{3}$ Plant throughput exceeded that of any previous month by 27 percent. Overall, the 1956 plant production exceeded that of 1955 by 57 percent. Another salient improvement made during 1956 was the replacement of the old, 900-pound drums used for offsite shipping of the $\mathrm{UO}_{3}$ powder with new T-hoppers. These containers left the site on specially fitted rail flat cars and served as feed hoppers for the ORNL plant customer.

Installation of the last three of the continuous calciners was completed at the $\mathrm{UO}_{3}$ Plant in early 1957, and the 18 pot units were retired from service. The following year, new facilities that were needed to segregate regular UNH feed from that generated by the processing of enriched uranium in the REDOX Plant were installed in the $\mathrm{UO}_{3}$ Plant. The $\mathrm{UO}_{3}$ powder that resulted from processing the two types of UNH streams had significantly different reactivity levels, and separation was needed by the customer at ORNL. Also in 1958, the $\mathrm{UO}_{3}$ Plant established another high production record that was 5.5 percent higher than that of 1957, and almost double that of 1954.

In 1958, the TBP Plant finished its mission and shut down. However, its feed to the $\mathrm{UO}_{3}$ Plant was far surpassed by that coming from the PUREX Plant. Together, the $\mathrm{UO}_{3}$ and PUREX Plants went on to set and surpass production records almost continually, while the REDOX Plant continued to supply a small stream of enriched UNH until its shutdown in 1967. During 1959, the concentration equipment and the acid recovery system at the $\mathrm{UO}_{3}$ Plant were automated, and in 1960, for the first time, the calciners were programmed so that they could be operated and shut down remotely. Steep production climbs at the plant continued. By 1963, production of $\mathrm{UO}_{3}$ actually shipped offsite rose to about 12,000 tons per year, and the capability was added to process UNH derived from uranium of even higher enrichment levels. 
Beginning in 1967, $\mathrm{UO}_{3}$ Plant operations were tied exclusively to those of the PUREX Plant. Both plants closed in 1972, and PUREX resumed operations in late 1983 , closely followed by $\mathrm{UO}_{3}$ in early 1984 . Since that time, there have been 17 different processing runs at the $\mathrm{UO}_{3}$ Plant, averaging 4 to 21 days each, because the plant could calcine UNH at a much faster rate than the PUREX Plant could produce it. Final deactivation orders came for both plants in 1992. In April 1993, the $\mathrm{UO}_{3}$ Plant resumed operations to convert 200,000 gallons of remaining UNH to uranium oxide powder. This run, completed in June, was the plant's last. A final deactivation plan for the facility, written in the summer of 1993, will be carried out by September 30, 1996.



The 224-UA Building, sometimes known as the Metal Conversion Facility, under construction in 1955. 
WHC-MR-0435

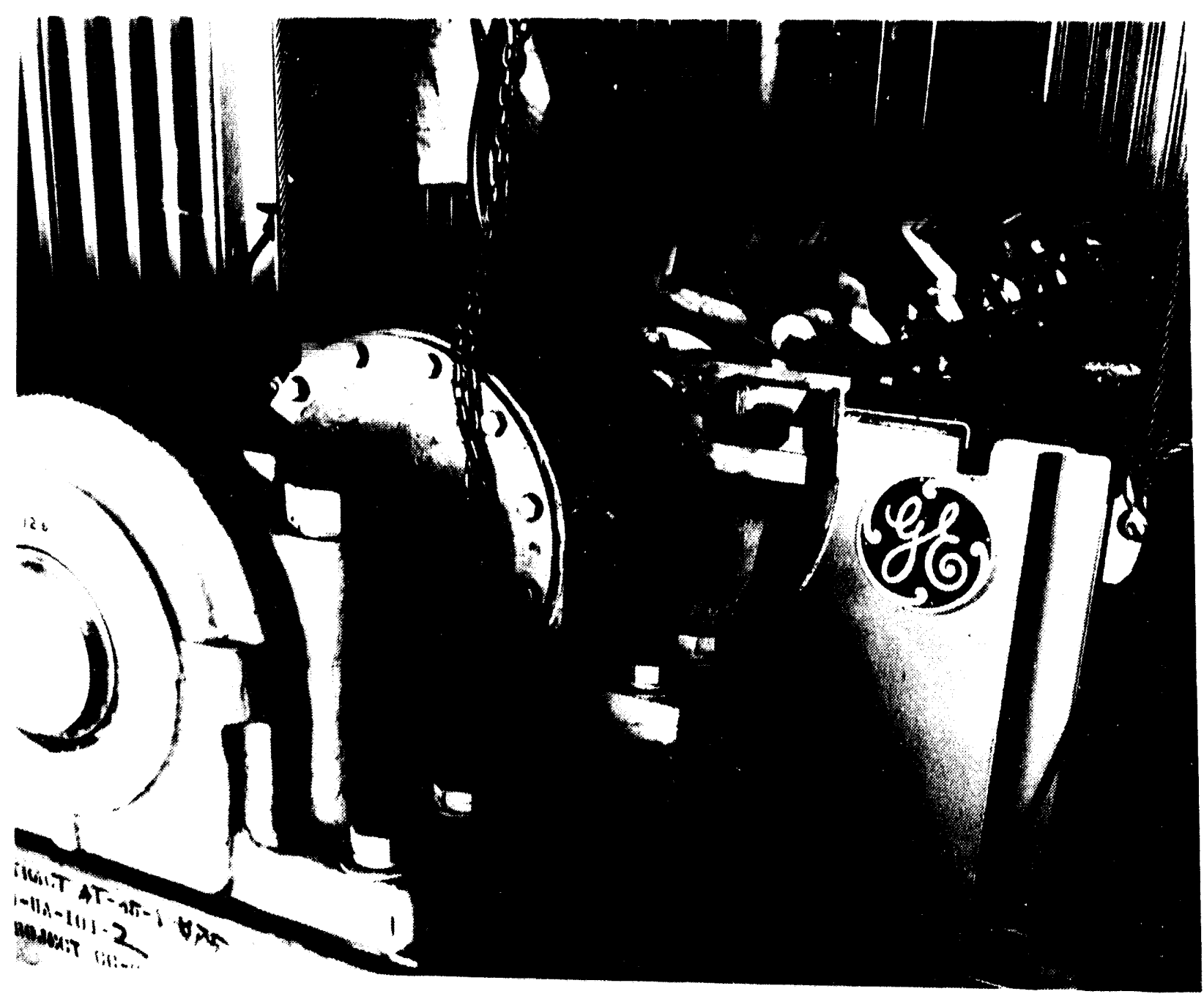

New continuous calciners being installed in the 224-UA Building (part of the $\mathrm{UO}_{3}$ Plant) in 1956. 




The PUREX Plant under construction in October 1953. 


\section{PUREX Plant: The Hantord Site's Historic Workhorse}

\section{GENESIS}

The PUREX Plant, now prefaring for deactivation, was conceived amidst some of the direst imperatives of the early Cold War years. New defense projections, drawn up by the Atomic Energy Commission and the Department of Defense (DOD) as the Korean War escalated in late 1950 and early 1951 , showed a gap between capacity and need, even as the new REDOX Plant was about to come on line at Hanford Works. Quickly, criteria were developed for "Program X", a new separations plant capable of processing 200 metric tons of irradiated, aluminum-clad uranium per month (MTU $\backslash \mathrm{m})$, with a built-in potential to increase to $400 \mathrm{MTU} \backslash \mathrm{m}$ with future equipment changes. This capacity would be necessary to handle material generated by the twin "jumbo" reactors, $105-\mathrm{KE}$ and $105-\mathrm{KW}$, new plants also planned at Hanford Works in the early 1950s.

Specific design engineering for the new processing facility began in July 1952, construction began in April 1953, and the PUREX plant was essentially complete by April 1955. Cold runs (tests with unirradiated materials) were initiated in late 1955, and hot startup (work with radioactive substances) commenced in January 1956.

The PUREX plant is a concrete rectangle 306.3 meters (1,005 feet) long, 31.7 meters (104 feet) high [with approximately 12.2 of those meters
(40 feet) below grade], and 18.7 meters (61.5 feet) wide. It's main "canyon" portion contains 11 cells designated A through $\mathrm{H}, \mathrm{J}, \mathrm{K}$, and $\mathrm{L}$, for irradiated metal dissolving, storage, the preparation of dissolved metal into feed solution for the PUREX process, waste treatment and acid recovery, organic solvent recovery, and solvent extraction and product concentration steps.

\section{UNIQUE DESIGN FEATURES}

The design of PUREX Plant equipment and systems incorporated several unique new features. Most important to overall operations was the use of pulse columns rather than packed columns to achieve actual chemical separation. Packed columns had been used in the REDOX Plant, and had necessitated the construction of the tall silo or "penthouse" on the west end of that structure. Such columns were ruled out early in the design of the PUREX Plant because a height reduction of 50 percent, with attendant financial savings, could be achieved if other means were used. In the three years from 1950 to 1953,50 years of research and development was applied to perfecting the PUREX pulse column design. One new feature was the insertion of swirl plates into the columns at several heights, to improve contact and mixing of the aqueous and organic solutions by reducing channeling effects. Additionally, the overall ventilation system that served the PUREX Plant was designed to have three times the capacity of the REDOX 
Plant system, so that air of nearly tornadic force could be blown into the cells when cover blocks were removed, and thus prevent the escape of contaminated particles from the cells into the canyon area.

\section{PRODUCTION CAPACITY AMAZING}

As the PUREX Plant was being built during 1954 and 1955, a simultaneous project was underway at Hanford Works to upgrade and increase the processing capacity at the World War II B- and T-Plants. Known as the 4X Program because it planned to use the capabilities of all four of the Hanford processing plants (B, T, REDOX, and PUREX), this endeavor actually completed renovations at B-Plant in December 1955 and was fully involved in the design phase of T-Plant upgrades. However, the first year of PUREX operations demonstrated such an overwhelming production capacity, along with economic efficiency compared to the other separations plants, that the $4 \mathrm{X}$ Program was abandoned. T-Plant was shut down as a processing facility, and B-Plant, which had been closed since 1952, was not re-started.

PUREX Plant production was expressed as the "instantaneous rate," a measure of the capacity the plant could achieve when it was fully operational, not counting the initial dissolving periods (after shutdowns) that it took to fill all of the systems with solutions and the periods just before shutdowns when only the last steps of the process were operating. In other words, the instantaneous rate was the rate at which the plant could process material if its startups and shutdowns occurred instantly, instead of over a period of hours. The initial PUREX Plant instantaneous processing rate was calculated at about 8 MTU per day (MTU/d), and this was called the "capacity factor."

However, by September 1956, after just 8 months of operation, the PUREX Plant demonstrated a sustained, instantaneous rate of $16 \mathrm{MTU} / \mathrm{d}$, and an astounding on-line efficiency of 99 percent. That year, the PUREX Plant processed 56 percent of the total plutonium output of Hanford Works, and the 1956 total output was itself 59 percent above that of 1955. The following year, the total output of plutonium from Hanford Works increased by 54 percent over that of 1956 , with the PUREX Plant processing 71 percent of this new total. That October, the plant demonstrated an instantaneous production rate of $20 \mathrm{MTU} / \mathrm{d}$, with a reduction in the amount of residual fission product activity in the product of 25 fold below design specifications. During 1958, the total Hanford Works output of plutonium increased five percent over that of 1957, with the PUREX Plant contributing 79 percent of that total. That year, the decision was made to send virtually all of the standard irradiated uranium from the 100 Areas production reactors to the PUREX Plant, and to divert "94 Metal" (enriched uranium containing .947 percent uranium 235 by weight) to the REDOX Plant. Additionally in 1958, the PUREX facility began the recovery of neptunium 237 (Np-237) on an occasional batch basis from its normal product stream. Immediately, the plant became the Atomic Energy Commission's prime supplier of this isotope. 


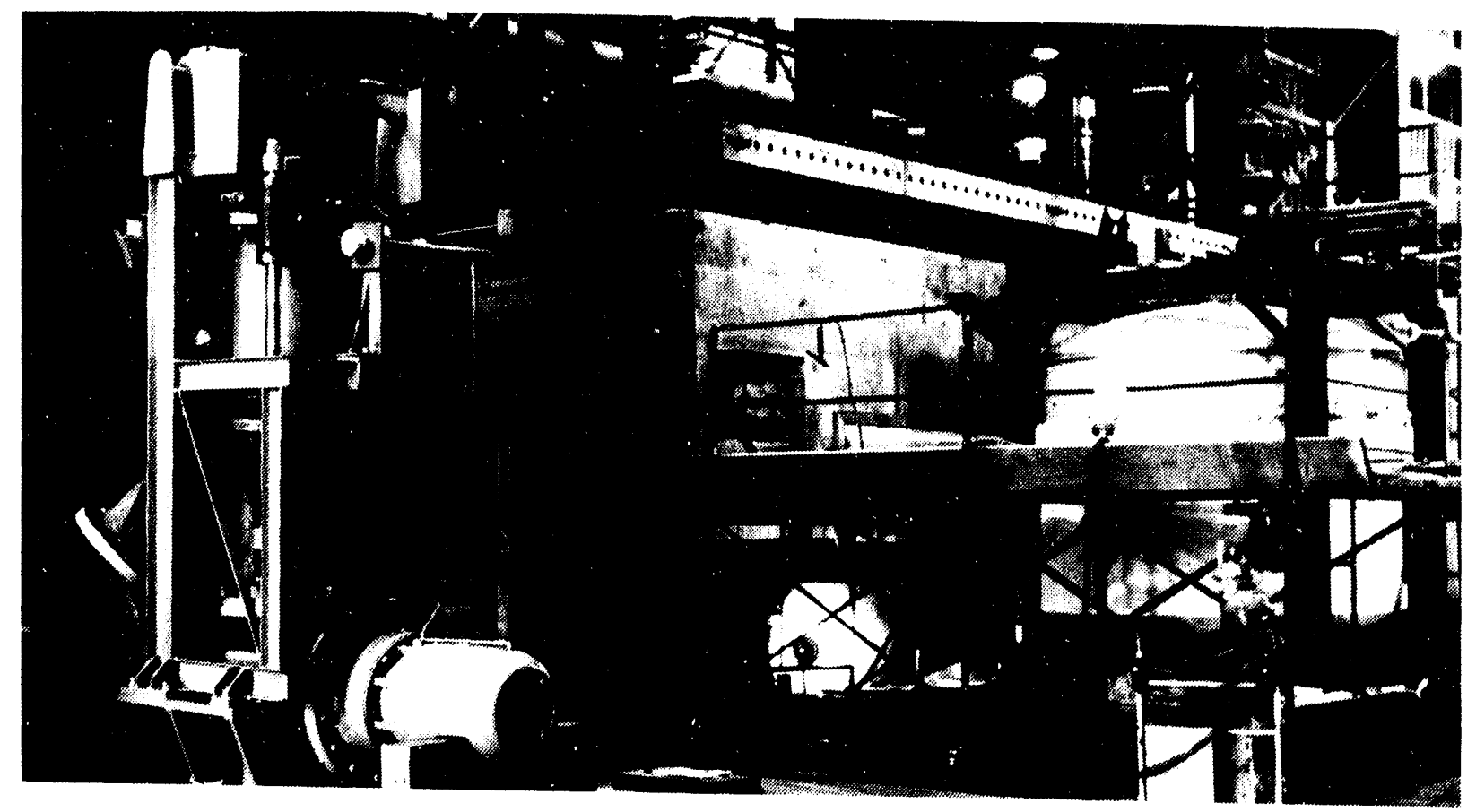

This mock-up of PUREX equipment was installed and tested in the 272-E Area Ship while the actual PUREX Facility was being constructed in 1954.

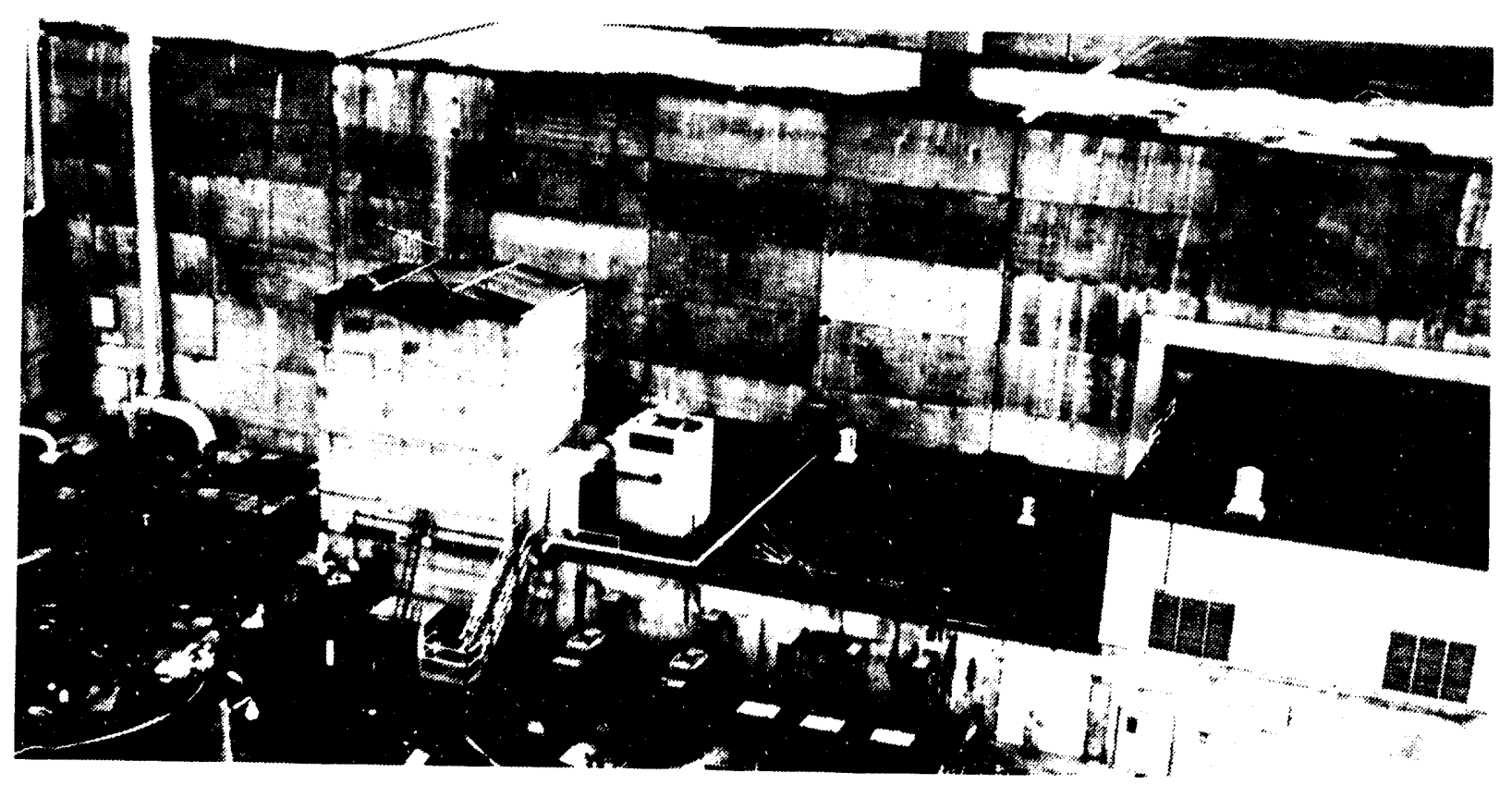

Additional off-gas treatment facilities under construction at the PUREX Plant in late 1956. 
The late 1950 s and early 1960 s witnessed even more spectacular production leaps at the PUREX facility. In October 1960, the plant reached the point of having processed 22,000 tons of irradiated fuel, thus surpassing the combined total of B-and T-Plants, and the REDOX facility, for all of their years of operations. For short periods of time, the PUREX Plant demonstrated the capacity to operate at 3.6 times its design capacity. The plant also exceeded its previous Np-237 production figures by producing 7.4 kilograms $(\mathrm{Kg})$ or 92 percent of the national supply. During the five years including 1960-1964, the two Hanford Works separations plants processed approximately 35,000 tons of irradiated fuel, with the PUREX Plant handling about 80 percent of that total. During 1962 , both the REDOX and PUREX Plants were modified to permit the continuous recovery of Np-237 without interfering with normal plutonium recovery operations. In late 1965, other PUREX Plant systems were modified to allow the plant to sustain normal operations at a 4.0 capacity factor, or nearly $33 \mathrm{MTU} / \mathrm{d}$.

Over the next few years, the PUREX Plant was modified to allow for the processing of various other fuel types, including fuel from N-Reactor, Hanford Works Plutonium Recycle Test Reactor (PRTR), thoria fuel targets, and other feeds. N-Reactor fuel elements were much larger than elements from Hanford Works single-pass reactors, and their Zircaloy-2 cladding was harder and slower to dissolve than the aluminum cladding of older fuel elements. Therefore, once the separation of $\mathrm{N}$-Reactor fuel began in 1967, the entire context of production rates and numbers changed for the PUREX
Plant. Whereas the processing 5,000 7,000 MTU per year (MTU/y) had been normal for the plant during the early years of the 1960s, when single-pass reactor slugs had comprised the irradiated portion of the feed material, the processing rate fell to about 2,000 MTU/y for N-Reactor fuel. Even lower rates occurred in some years, because of interruptions by special recovery campaigns.

\section{SOLE PROVIDER}

In 1967, the REDOX Plant closed, and the PUREX Plant became the sole, operating processing facility at Hanford. In 1972, the PUREX Plant entered a temporary shutdown period that was planned for 18 months but lasted for 11 years. During the shutdown period, many upgrade projects were completed, and many changes occurred involving waste management and environmental issues.

In 1983, the PUREX Plant reopened with an operating limit allowing it to process up to 3,000 MTU/y of N-Reactor fuel, or about $8 \mathrm{MTU} / \mathrm{d}$. However, the highest sustained short-term production rates in the ensuing years hovered near 7 MTU/d, and the highest long-term rates hovered near $3 \mathrm{MTU} / \mathrm{d}$. In October 1990, the PUREX Plant was placed on standby status by the DOE. A final closure order was issued on December 1992, and a transition plan was prepared in 1993 that will take the facility through full deactivation in the next few years. At some point, the historic status of the plant also will be reviewed under the National Historic Preservation Act. 


\section{PUREX Plant Waste Management Was a Complex Challenge}

\section{SEVEN ORIGINAL CRIBS}

Waste management has always presented complex challenges for the PUREX Plant both in terms of the volume produced and the widely variant radioactivity levels of different waste forms. Originally, seven disposal facilities, known as cribs or 216 structures, were provided to handle low-level liquid wastes. Organic waste from solvent treatment operations and from the waste disposal cell in the 202-A (PUREX) Building went to the 216-A-2 crib, while laboratory and cell drain waste went to the 216-A-4 facility. Drainage from the facility that stored the recovered uranium product from the PUREX process, as well as from the acid fractionator (recovery equipment) went to the 216-A-3 crib, while process condensate, steam condensate, and tank farm diversion box drainage went to three other cribs. Condenser cooling water and condensate from the 241-A Tank Farm was disposed to the 216-A-8 crib. Raw water employed in the PUREX process for cooling and general utility purposes was piped to a cooling water swamp located southeast of the main PUREX Plant structure. A small portion of this water was collected in the steel, 201-A storage tank for use in cooling the contact condensers of the 241-A Tank Farm.

\section{GROUNDWATER MOUNDS COMPLICATE DISPOSAL}

As soon as the PUREX Plant began operations, disposal of low-level liquid wastes from it became complicated by mounds that had developed in the groundwater beneath both the 200-East and the 200-West Areas as the result of cooling water discharges from other Hanford Site separations plants. These mounds shifted natural hydraulic gradients and drainage patterns, sometimes intersecting with underground plumes of contaminated liquids and routing them towards areas of high permeability and transmissibility. Also, the pressure and weight of the mounds themselves increased the hydrostatic head, forcing all nearby or affected underground liquids to travel faster toward the Columbia River. By October 1955, three years after the closure of B-Plant, the groundwater mound beneath the 200-East Area had dropped 10 feet from its peak of 405 feet.

However, just eight months after startup of the PUREX Plant, the facility's swamp discharges of 24.6 million liters (6.5 million gallons) per day raised the groundwater mound beneath the 200-East Area to 127.4 meters (418 feet), higher than at any previous time. Furthermore, wastes from the 216-A-8 crib reached groundwater in December 1956, and during the next three months, beta activity in groundwater samples beneath this crib increased by 100,000 times. 
A theory with widespread acceptance at Hanford Works at that time was that the movement of underground water could be controlled by the strategic and deliberate formation of groundwater mounds that would act as "hydrologic dams." The speculation was that such mounds would counterbalance each other, and enable scientists to divert underground water through desirable pathways by carefully controlling and rotating discharges to certain swamps. In the case of the PUREX Plant, it was believed that the underground pathways of cooling water could be managed by distributing the majority of such water to the Gable Mountain swamp (to the north of the plant), about 20 percent to the swamp southeast of the plant, and about 10 percent to B-Pond (east of the plant).

\section{MANY SOLUTIONS TRIED}

As a result of the hydraulic dam theory, a project was undertaken to reroute PUREX Plant cooling water, but by the time the diversion was completed, the enormous PUREX Plant production capacity had raised the average daily cooling water discharges to 37.1 million liters (9.8 million gallons) per day. At the same time, scientists learned that patterns in groundwater beneath Hanford were too complex to control. Wastes from the PUREX cribs continued to reach groundwater, intersect with the mound southeast of the plant, and travel into "permeable zones." These effects continued and grew throughout the production leaps of the late 1950s and the 1960s. During the same period, many changes and solutions were tried, including replacing various cribs, installing surface condensers in the 241-A Tank Farm (in 1959), and conducting experiments in decontaminating PUREX tank farm condensates with natural and synthetic ion exchange resins.

During and following the 1972-1983 PUREX Plant shutdown, many additional changes were made to re-route, treat, and minimize low level waste discharges. Among these were the installation of a tank farm condensate recycling system, the construction of new cribs, and the installation of monitors and diversion flow systems. Pursuant to agreements made in the 1989 Hanford Federal Facility Agreement and Consent Order (Tri-Party Agreement), all untreated, low-level liquid discharges from the PUREX facility, and from other Hanford plants, must cease in 1995 (Ecology et al. 1990).

\section{1-A TANK FARM BUILT TO PREVENT "BUMPING"}

The management of high level wastes at the PUREX Plant originally was based on the six tanks of the 241-A Tank Farm, located approximately 457.2 meters (1,500 feet) northeast of the midpoint of the 202-A Building. Each tank was 22.9 meters (75 feet) in diameter, with a capacity of $3,785,400$ liters (one million gallons). The designers of these tanks had learned some key lessons from the first experiences with self-boiling wastes at the REDOX Plant in 1952-53. At that time, radioactive wastes that had boiled from the self-generated heat of the decay reactions taking place in them had ruptured the cooling coils of the 241-S tanks and spread contamination to nearby areas. Hanford Works scientists called the phenomenon "bumping" because heat built up in the waste layers and then released itself in periodic bursts. 


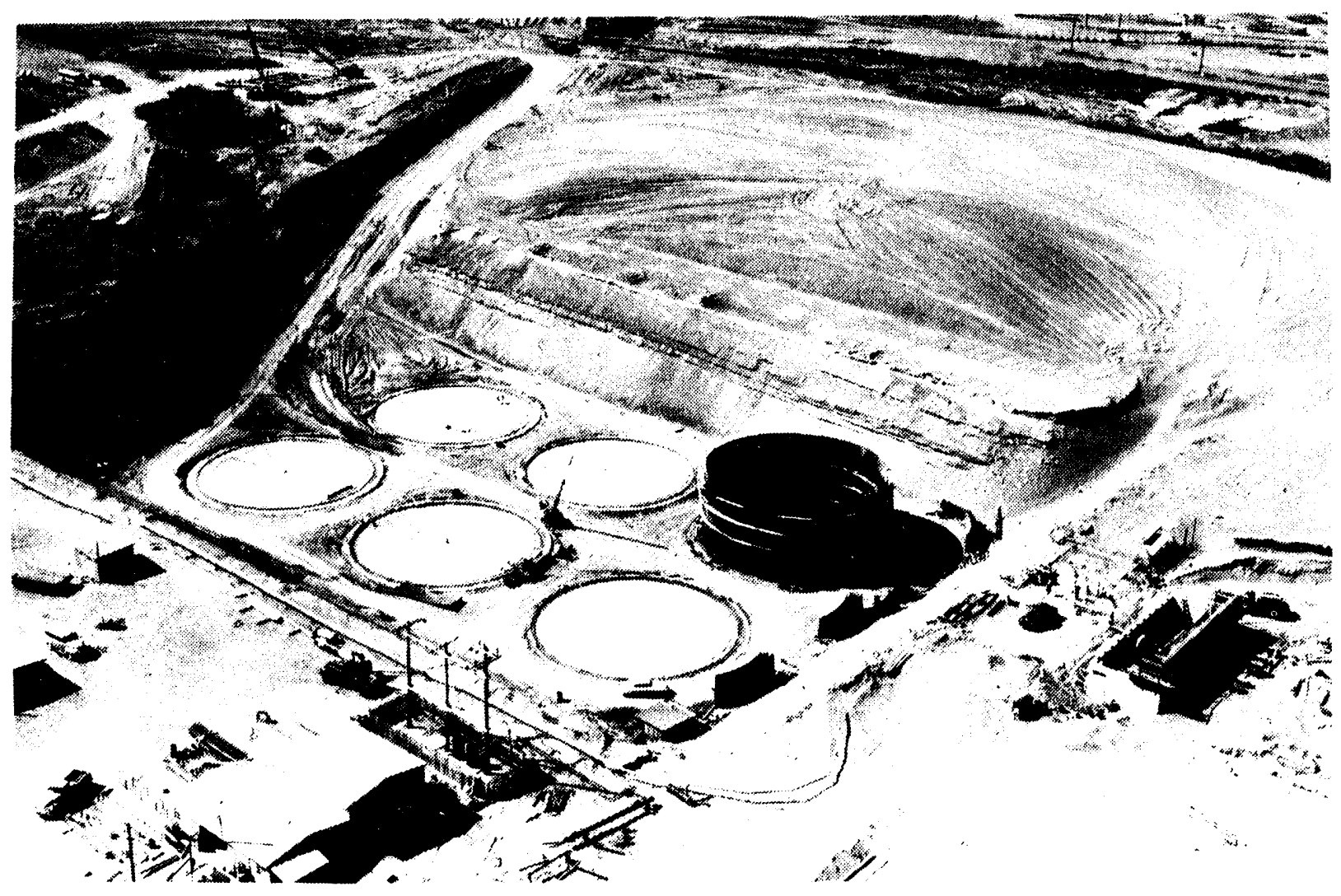

The 241-A Tank Farm, serving the PUREX Facility, under construction in 1954.

In order to avoid bumping and to provide for the proper control of temperatures, the 241-A tanks each were equipped with four air-lift circulators (mixers) that used forced air to lift and "stir" the wastes. Another key feature designed to allow management of selfboiling tank wastes in the 241-A Tank Farm was the vapor system, through which all of the tanks were interconnected by a 24 -inch vapor header. Additional cooling water could be supplied to the condensers in the high-level waste from the 201-A water storage tank, and each of the 241-A tanks (except for the last tank in the line -- 241-A-106) had an overflow line that connected it to the next tank in the series.

\section{NOT ENOUGH TANK SPACE}

While the new system worked well during the early years of PUREX Plant operations, the ubiquitous Hanford Site problem of shortfalls in high-level waste tank space soon affected the huge plant. By mid-1956, it was predicted that a new PUREX tank farm could be needed as early as 1958. Coating removal (fuel decladding) wastes from the plant averaged 1,075 liters (284 gallons) per ton of production, and were sent to the Word War II era 241-C Tank Farm. Finding a way to bind up or decontaminate the coating wastes to the point that they would be eligible for disposal in soil or in underground "caverns" became a high priority during 1957-1958. However, 
although studies in the gelation of such wastes with chemical additives were initially promising, it had been demonstrated by late 1958 that the gels were unstable and did not provide good radionuclide retention over time.

Studies in how to manage high-level liquid wastes at Hanford Works then broadened into several pathways. Additional leak-detection systems for self boiling tanks were developed, various tank construction materials such as titanium were explored for corrosion resistance and for other factors, and the question of the ultimate disposal (as opposed to in-tank storage) of high-level wastes began to be explored in depth. A powerful and longrunning debate ensued at the Hanford Site, between those who advocated the solidification of high-level wastes into glass-like, solid forms, and those who favored partitioning of the wastes into various isotopes for space power, medical, and other uses. While the debate continued, the rapidly expanding PUREX Plant production capacity demanded more storage tanks. During 1963-1964, the AX Tank Farm, comprised of the last four single-shell,

The 241-AW Tank

Farm, consisting of six double-shell tanks that served the PUREX Facility, under construction in 1975. high-level waste tanks (SSTs) to be built at Hanford Works, was constructed to serve the plant. The first two double-shell tanks (DSTs) were built for the PUREX Plant in the AY Tank Farm during 1968-1970. At the AZ, AW, and AN Tank Farms, Fifteen more DSTs were constructed for the PUREX Plant during its 1972-1983 shutdown period. During the 1983-1988 period, eight more DSTs were built for the giant plant in the AP Tank Farm.

\section{BURIAL TUNNELS UNIQUE}

Large pieces of solid radioactive wastes, such as failed or outworn equipment, have been disposed at the PUREX Plant over the years in a unique way. A 152.4 meter (500-foot) extension, running toward the south, was built onto the single-track rail tunnel that brought irradiated slugs to the east end of the PUREX Building, and the waste pieces were pushed up the tunnel on flat rail cars. In 1964, a new, 457.2 meter (1,500-foot) tunnel was constructed after the first one had become full. In the near future, a final closure plan for these tunnels will need to be prepared.

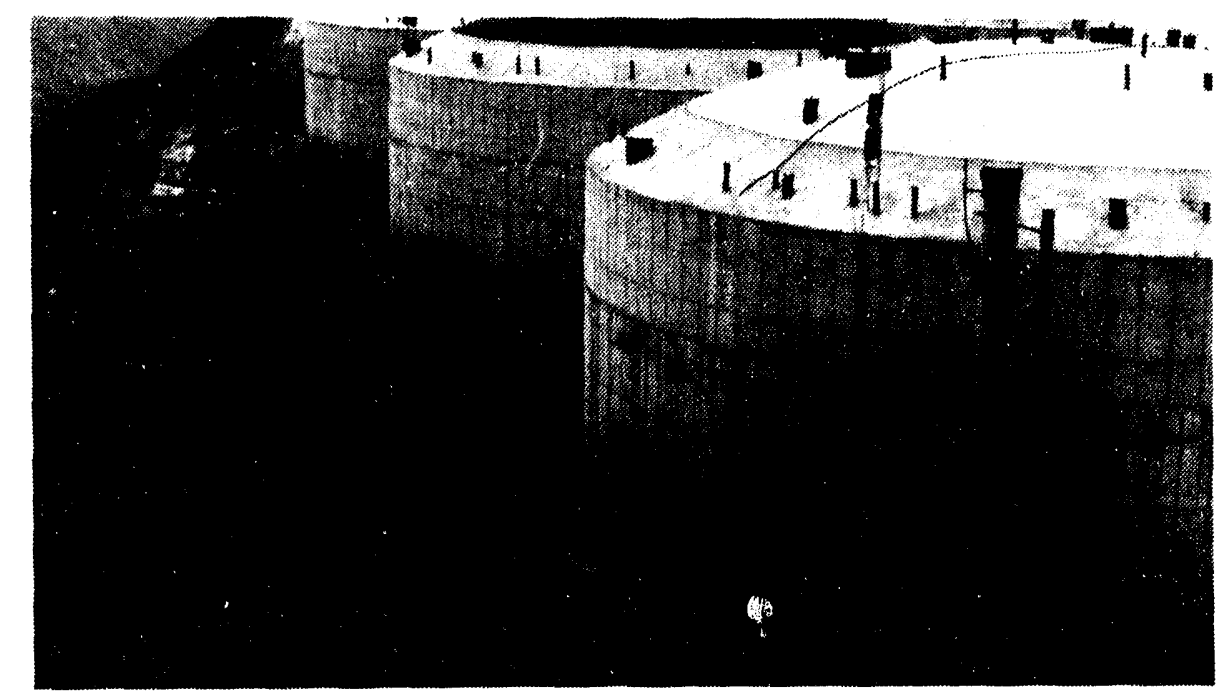


WHC-MR-0435

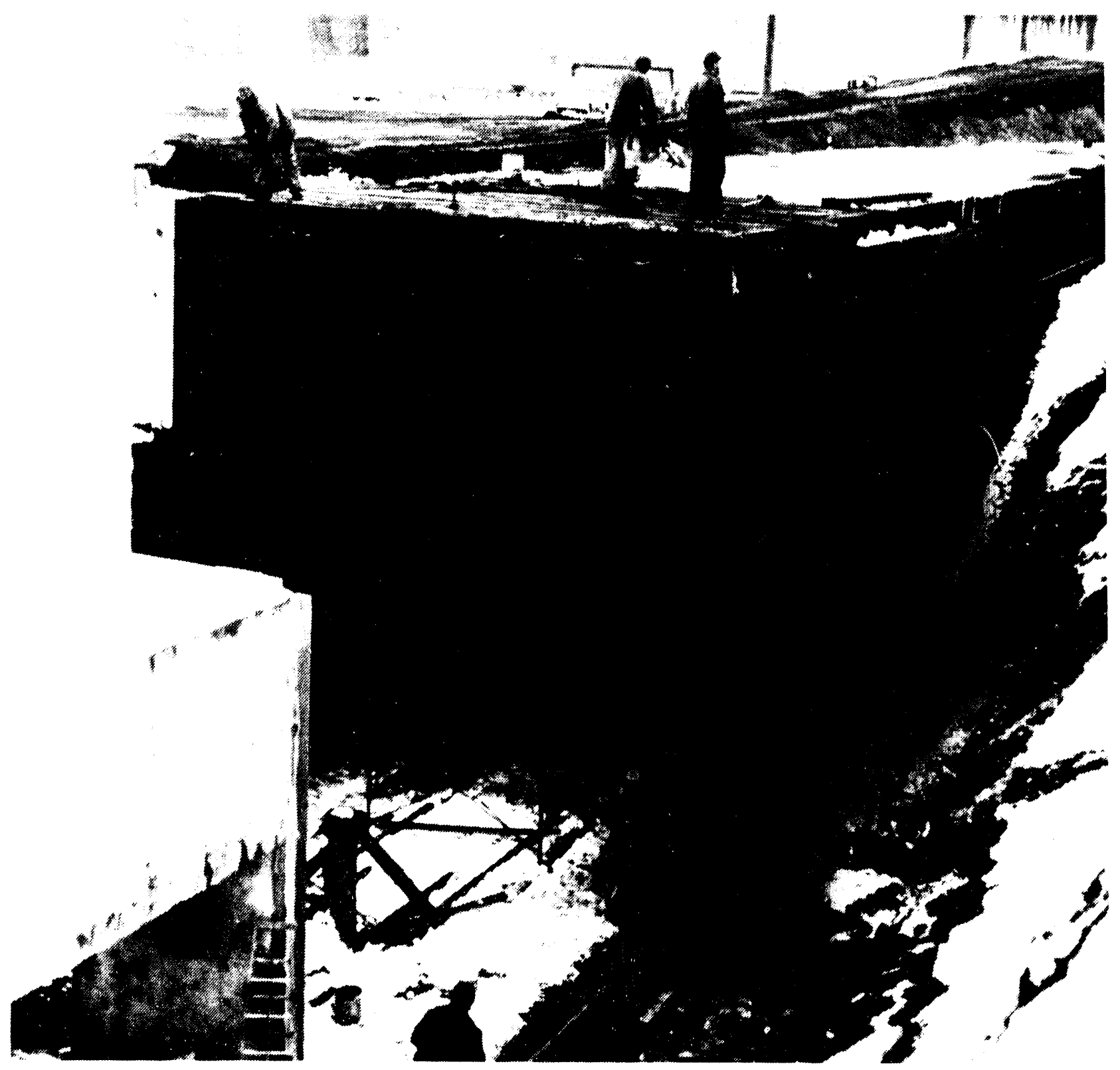

The original PUREX burial tunnel for large pieces of contaminated solid waste, under construction in 1954. 




The second PUREX burial tunnel, approximately three times as long as the original tunnel, under construction in 1964. 


\section{Early Hanford Site Codes and Jargon}

Code words (sometimes officially classified secrets), code names, and "Hanfordese" (slang or jargon) designations were sprinkled throughout the early operations of the top-secret Hanford Site. The following guide is intended as a fun, but not complete, lexicon that may be useful in helping the average reader decipher some of the Hanford Site's historical documents.

94 Metal - Enriched uranium containing .947 percent U-235 by weight.

125 Metal - Enriched uranium containing 1.25 percent $\mathrm{U}-235$ by weight.

210 Metal (also known as Driver Elements) - Enriched uranium containing 2.10 percent U-235 by weight.

"B"-Material (also known as "B"-Metal) Target fuel elements comprised mainly of bismuth with a small proportion of lead. B-Material was irradiated to produce polonium-210, an alpha-emitter that could be combined with a light element such as beryllium or boron to make a source of neutrons. This material, in turn, served as the initiator in early atomic weapons.
"C"-Slugs (also known as "C"-Metal) Fuel elements in which uranium was alloyed with aluminum. They contained 4.3 percent $U-235$ by weight.

"E"-Slugs (also known as Eisenhower Slugs, like Slugs, or "E"-Metal) Fuel elements enriched to 1.75 percent U-235 by weight.

"F" Material - Finished or purified graphite.

"J"-Slugs (also known as "J"-Metal or "Oralloy") - Fuel elements in which uranium was alloyed with aluminum. They contained 7.5 percent U-235 by weight, (but 93.5 percent of the uranium content was U-235).

MJ-1 - The reduction oxidation (REDOX) process.

MJ-2 - The 234-5 (Plutonium Finishing Plant) facility.

MJ-3 - The Radioactive Lanthanum (RALA) process. See RALA.

MJ-4 - The tributyl-phosphate (TBP) process used at U-Plant in the 1950s.

MJ-5 - The process of converting uranyl nitrate hexahydrate (UNH) to $\mathrm{UO}_{3}$.

"P" Material - Reactor poisons (neutronabsorbing materials). 
P-10 Project - The late 1940s and early 1950s program to produce tritium, a key component in hydrogen or thermonuclear weapons, at the Hanford Site. The irradiations of bismuth ("B"-Material) took place in the $\mathrm{H}$ and $\mathrm{B}$ Reactors, and the separations processing took place in the 108-B Building. The tritium production program transferred to the Savannah River Plant in late 1952. P-10 was the code for tritium.

P-13 Project - An experiment conducted in H-reactor in which a test channel was devoted to trials of Navy fuel materials.

"Q"-Slugs (Also known as "Q"-metal or "10-66" material) - Thorium fuel targets tested in the mid-1950's for the production of U-233. Not the same as "Myrnalloy" thorium fuels.

SCRAM - Safety Control Rod Ax Man Derived as an acronym from the fact that the control rods in the first critical pile at Stagg Field at the University of Chicago were suspended by a rope. In case of need, the rope was to have been cut with an ax to lower the rods into the pile. In general use, the term referred to the sudden shutting down of a reactor, usually by dropping of safety rods. At the Hanford Site, a Number One scram was the insertion of both Horizontal Control Rods (HCRs) and Vertical Safety Rods (VSRs) simultaneously as rapidly as possible. A Number Two scram was accomplished by inserting only the HCRs as rapidly as possible.
W Slug - A uranium fuel element manufactured at the Hanford Site.

X-Levels - Access areas to the Hanford Site reactor test holes. Located on the right for "far" sides of the reactors, level $X_{0}$ was on the main floor of the reactor buildings, level $X_{1}$ was 4.6 meters (15 feet) above $X_{0}$, and level $X_{2}$ was 4.6 meters (15 feet) above $X_{1}$.

Z-Metal - Lithium.

Base Metal - Fresh uranium.

Bayonet - A sampling device approximately .6 meters ( 2 feet) in length and fitted with a disposable pipette, used to take process samples from second cycle and subsequent operations in the early chemical separations processes.

\section{Bumper Fuel Element (or Bumper Slug)}

- A fuel element on which "bumpers" (fin-like projections) were welded, allowing freer water flow through ribbed process tubes in order to prevent hot spots and ruptures.

Can - The cladding around a uranium fuel core.

Clam-Shells - The 1940's pneumatic charge-discharge machines used at the Hanford Site's reactors.

Cold Slugs - Unirradiated or "green" fuel elements. 


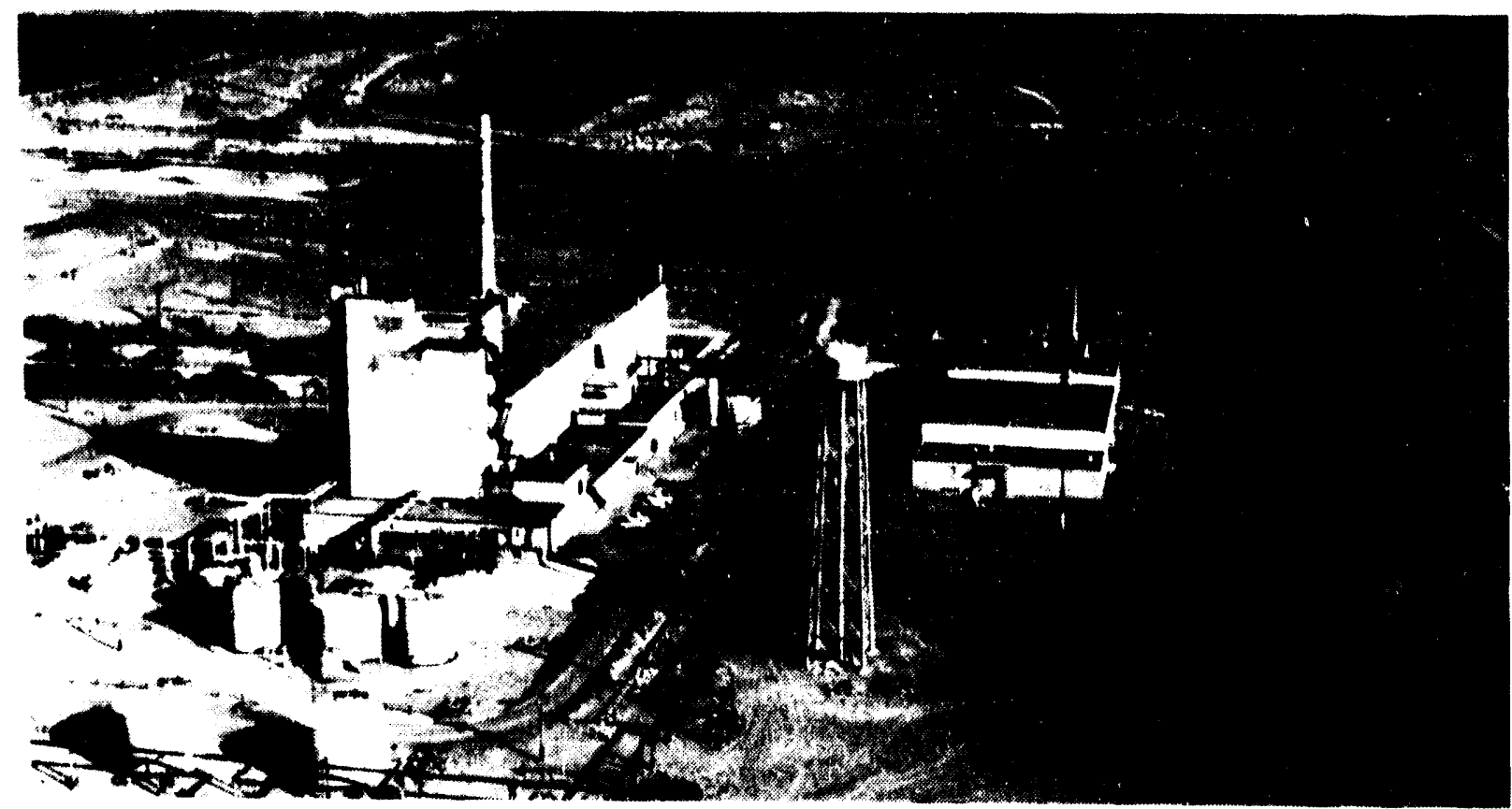

The REDOX plant in the 200-West Area, shown in 1953, conducted secret chemical separations work under the code name MJ-1.

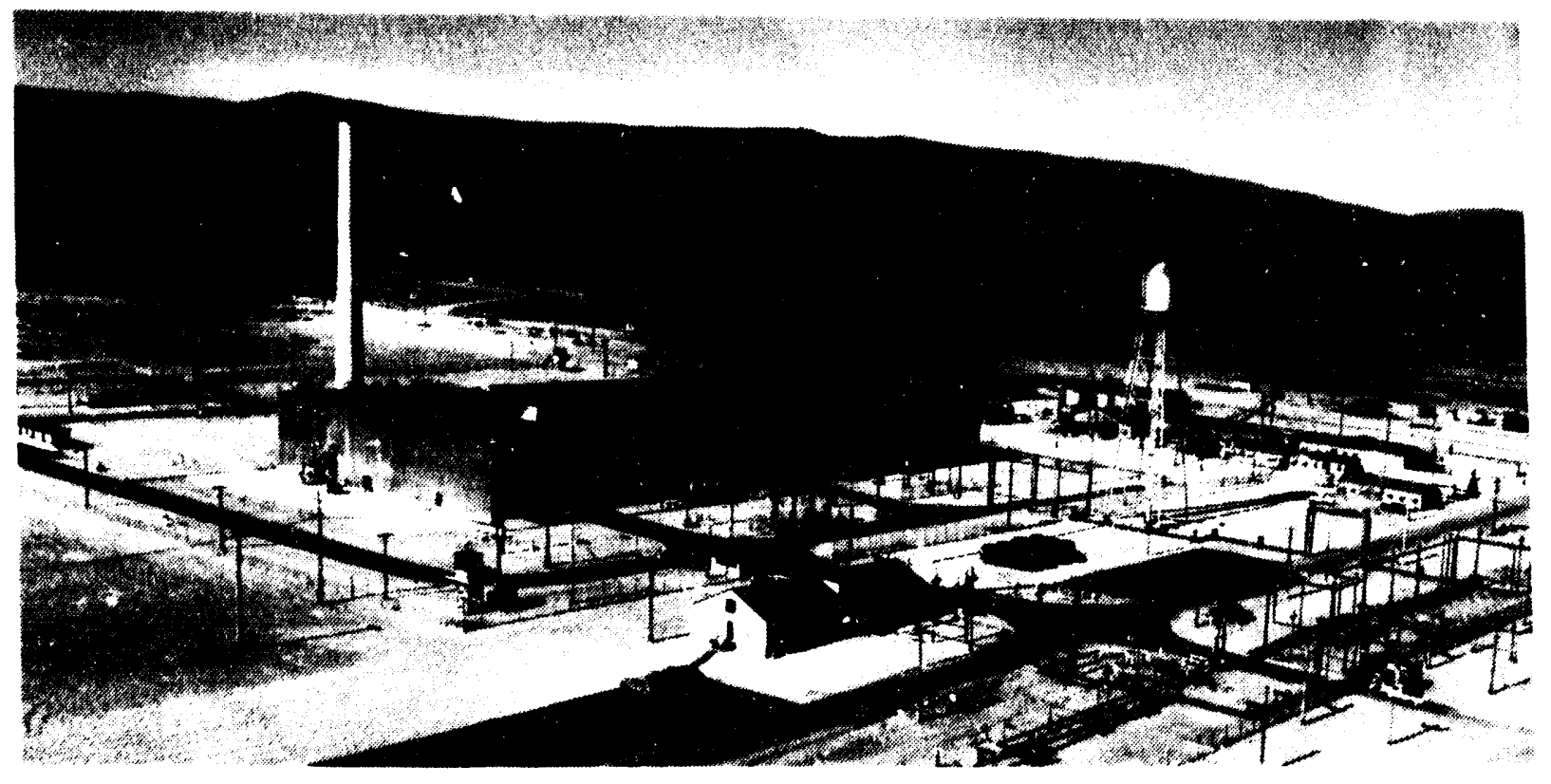

The 234-5 Building, also known as the Plutonium Finishing Plant, shown new in 1949, was one of the most secret places at Hanford Works. Here, in the 200-West Area, the products of the Site's chemical separations plants were converted into metallic plutonium. The facility operated in its early years under the code name MJ-2. 
Co-product - At the Hanford Site, the production of tritium in a reactor whose primary product was plutonium. A more general interpretation would include any isotope produced in the same reactor as the major product, but not including by-products, such as gratuitous neptunium.

Dummies (also known as Spacers) - Nonfissionable, solid tubular, perforated tubular, and even poison and steel cylinders resembling fuel elements, used to create spacing and neutron barriers within process tubes.

Eggs - Samples cut off of the ends of newly arrived uranium billets and tested for impurities before the billets were fabricated into fuel elements.

Fish Tail - Designation for a uranium fuel element rejected because of discontinuities in the rolled ends.

Flash - Noun - A sudden and temporary spike in radioactivity or chemical levels within a substance or the environment.

Grizzlies (also known as Strainers) - The large grates on the 1904 outfall piping that led from the reactors to the Columbia River.

Guillotine - Special tool developed and used at the Hanford Site to chop lengths of process tubes and poison splines into short segments as they came out of the discharge face of the reactors.
Hot - A slang term for materials that are radioactive, usually above the state found in nature, as a result of exposure to radiation.

Kitten - A batch of plutonium-bearing solution that was re-run through $\mathrm{T}$ or B Plants because it contained a prohibited amount of product.

Maple - F Reactor, during World War II.

Myrnalloy Slugs - Thorium fuel elements in solid metallic form that were tried in the early 1950 s as reactor poisons. Myrnalloys were not used as target elements.

Noodle - A plastic cylinder that was pushed through reactor process tubes after " $D$ " operations to make sure that the tubes were empty of irradiated charges.

Olive - B Reactor, during World War II.

Papoose - A short, threaded sample can that could attach to a uranium fuel element and be inserted into the process tubes of a reactor for the irradiation of very small samples.

Peanut - A 0.3 milliliter capacity container for samples from the 231 Building.

Phoenix - A shipping cask for "RALA" or MJ-3 material (See RALA).

Pine - D Reactor, during World War II.

Product (also known as PR or 49) Plutonium-239. 
Push - The act of discharging material from the reactors. As a noun, the term sometimes referred to the discharged material itself.

Quickie - A brief shutdown of a reactor for rapid removal of a ruptured fuel element from a process tube, with startup of the reactor before Xe-135 built up to a level that would poison the reactivity. The maximum time allowed for a quickie in the Hanford Site reactors was about 28 minutes, depending on the amount of excess reactivity in the reactor.

RALA (Radioactive Lanthanum) - A tracer gas used by the U.S. Air Force to measure the range of conventional explosives in the late 1940s and 1950s. Produced by the irradiation of barium, Rala wàs made in very small quantities at the Hanford Site in the late 1940s, before the production program moved to the Reactor Testing Station (now the Idaho National Engineering Laboratory). The Rala process was known as MJ-3.

Rails (also known as Ribs) - Projections welded to the inside of reactor process tubes to guide and seat the fuel elements.

Receptacle Slug - A uranium cylinder that was bored in the middle to contain a sample for insertion in a process tube when it was desired to surround the sample completely with uranium.
Ride the Rails - The seating of fuel eiements and dummies in ribbed process tubes. The rails (or ribs) provided support to the elements and dummies, and allowed water flow around them.

Site W - The earliest name for the Hanford Site. Los Alamos was Site $\mathrm{X}$, and the Clinton Site (now Oak Ridge) was Site $Y$.

Skull (also known as Dross) - The impure, solid metallic material that formed at the top of Z-Plant crucibles in which plutonium buttons were melted for formation into weapons shapes.

Slugs - An early term for uranium fuel elements in the form of short cylinders clad or encased in corrosion-resistant metals.

Splitter - A special equipment piece developed and used at the Hanford Site to split or break apart damaged process tubes in the reactors by inserting an internal probe that progressively widened until the tube metal parted. Splitting was a precursor to the removal of damaged tubes.

Thimbles - The early aluminum linings of Horizontal Control Rods, Vertical Safety Rods, and test holes. All thimbles were removed from Hanford Site reactors in the mid-to-late 1950s. 
Trampolines - Submerged chain nets in the irradiated fuel storage basins that absorbed the impact of free falling fuel elements being discharged from the reactors. Such devices were used only during World War II.

Weasel - A piece of radiation detection equipment with a long extension on the probe that was used to take gross gamma measurements on discharged fuel in the fuel storage basin in order to verify exposure calculations. As a verb, taking a measurement in this manner was referred to as "weaseling the fuel element."
Whiz-Bang - An electric heater press that was tried as the earliest method of attaching cladding to the cores of uranium fuel elements. This method had failed by the spring of 1944 , and was replaced by the triple-dip fuel cladding technique.



This massive 1956 billboard was one among many ubiquitous cautions to Hanford Works employees that the Hanford Site's business was top-secret. 


\section{Glossary}

94 Metal

A-J

BiPO4

BWIP

CBP

DOD

DSTs

FFTF

FMEF

HCRs

Hanford Engineer Works

Hanford Works

$\mathrm{Kg}$

MED

Met Lab

MTU

Np-237

ORNL
Enriched uranium containing .947 percent uranium- 235 by weight

Atkinson-Jones, a Hanford Site Construction Contractor

Bismuth-phosphate

Basalt Waste Isolation Project

Columbia Basin Irrigation Project

Department of Defense

Double-Shell Waste Tanks

Fast Flux Test Facility

Fuels and Materials Examination Facility

Horizontal Control Rods

The World War II name for the Hanford Site

The Atomic Energy Commission's post World War II name of the Hanford Site

Kilograms

Manhattan Engineer District - A wartime government agency that managed the Hanford Site, the Los Alamos Scientific Laboratory, and the Oak Ridge National Laboratory

Metallurgical Laboratory at the University of Ohio

Metric Tons of Irradiated Aluminum Clad Uranium

Neptunium-237

Oak Ridge National Laboratories 
WHC-MR-0435

\section{Glossary (continued)}

OSRD

PRTR

PUREX

REDOX

SSTs

Tri-Party Agreement

TRICNIC

UF6

UNH

$\mathrm{UO}_{3}$ Plant

VSRs

WAC

WPPSS
Office of Scientific Research and Development

Plutonium Recycle Test Reactor

Plutonium Uranium Extraction Plant

Reduction Oxidation Chemical Processing Plant

Single-Shell Waste Tanks

Hanford Federal Facility Agreement and Conser t Order

Tri-Cities Nuclear Industrial Council

Uranium Hexaflouride - The primary feed material for the United States' gaseous diffusion plants

Uranium Nitrate Hexahydrate - The uranium product stream that resulted from certain solvent extraction processes

Uranium Trioxide Plant

Vertical Safety Rods

Women's Army Corps

Washington Public Power Supply System 


\section{WHC-MR-0435}

\section{References}

Ecology, EPA, and DOE, 1990, Hanford Federal Facility Agreement and Consent Order, 2 Vols., as amended, Washington State Department of Ecology, U.S. Environmental Protection Agency, and U.S. Department of Energy, Olympia, Washington.

DuPont, 1945a, Design and Procurement History of hanford Engineer Works and Clinton Semi-Works, IN-6263, E. I. DuPont de Nemours and Co., Wilmington, Delaware.

DuPont, 1945b, Construction of Hanford Engineer Works: History of the Project, HAN-10970, Vol. 3, E. I. DuPont de Nemours and Co., Wilmington, Delaware.

DuPont, 1946, Operation of Hanford Engineer Engineer Works: History of the Project, HAN-73214, Book 13, "Fire Protection," E. I. DuPont de Nemours and Co., Wilmington, Delaware.

HEW, 1945, History of Operations, (1 January 1944 to 20 March 1945), OUT-1462, Hanford Engineer Works, Richland, Washington.

Mademoiselle, 1946, "Mademoiselle Merit Awards," January, 1946.

Maris, Buena, 1960, Hanford In Retrospect, No Number 0019, Westinghouse Hanford Company, Richland, Washington.

Matthias, Franklin T., 1987, Hanford Engineer Works, Manhattan Engineer District: Early History, Speech to the Technical Exchange Program, January 14, 1987, Richland, Washington.

Richland Villager, February 3, 1949, Richland, Washington.

Richland Villager, March 3, 1946, Richland, Washington.

\section{Additional Research Sources}

This booklet was prepared primarily with information gathered from research sources known as the Hanford Historical Documents. Over 100,000 pages of such material, including early construction and engineering reports, environmental monitoring reports, operating shift logs, memos, and correspondence from the early years of the Hanford Site, are available in the Department of Energy Public Reading Room, located in the library of the Washington State University at Tri-Cities Campus. Among those sources, the following documents were especially helpful.

DuPont Corporation, 1945, Construction of Hanford Engineer Works: History of the Project, HAN-10970, Vols. I - IV, E. I. DuPont de Nemours and Co., Wilmington, Delaware. 


\section{WHC-MR-0435}

\section{Sources (continued)}

DuPont Corporation, 1946, Operation of Hanford Engineer Works: History of the Project, HAN-73214, Introduction and Books 1-18, E. I. DuPont de Nemours and Co., Wilmington, Deleware.

DuPont Corporation, 1945, Design and Procurement History of Hanford Engineer Work and Clinton Semi-Works, IN-6263, Vols. I and II, E. I. DuPont de Nemours and Co., Wilmington, Deleware.

G.E. Hanford Co., 1955, PUREX Technical Manual, HW-31000-DEL, G.E. Hanford Co., Richland, Washington.

Hanford Engineer Works, 1945, History of Operations (1 January 1944 to 20 March 1945), OUT-1462, Hanford Engineer Works, Richland, Washington.

Hanford Engineer Works, 1944, Hanford Technical Manual, Sections B and C, HW-10475, Hanford Engineer Works, Richland, Washington.

Matthias, Franklin T., Journal and Notes, 1943-1945, Personal Journal, kept at U.S. Department of Energy Public Reading Room, Richland, Washington.

Additionally, the following books were helpful.

Gerber, Michele S., 1992, On the Home Front: The Cold War Legacy of the Hanford Nuclear Site, University of Nebraska Press, Lincoln, Nebraska.

Groves, Leslie R., 1962, Now It Can Be Told: The Story of the Manhattan Project, DaCapo Press, Inc., New York, New York.

Hacker, Barton C., 1962, The Dragon's Tail: Radiation Safety in the Manhattan Project, 1942-1946, University of California Press, Berkeley, California.

Hewlett, Richard G., and Anderson, Oscar E., Jr., 1962, The New World, 1939/1946, Pennsylvania State University Press, University Park, Pennsylvania.

Hewlett, R.G., and Duncan, F., 1972, Atomic Shield: A History of the United States Atomic Energy Commission, WASH-1215, U.S. Atomic Energy Commission, Washington, D.C.

Hewlett, R.G., and Holl, J.M., 1989, Atoms for Peace and War, 1953-1961: Eisenhower and the Atomic Energy Commission, University of California Press, Berkeley, California.

Jones, Vincent C., 1985, Manhattan: The Army and the Bomb, U.S. Center for Military History, Washington, D.C.

Libby, Leona M., 1979, The Uranium People, Crane, Russak Inc., New York, New York.

Nichols, Kenneth D., 1987, The Road to Trinity, William Morrow and Co., New York, New York.

Rhodes, Richard, 1984, The Making of the Atomic Bomb, Simon and Schuster, Inc., New York, New York.

Sanger, Steven L., 1989, Hanford and the Bomb: An Oral History of World War II, Living History Press, Seattle, Washington.

Smyth, Henry D., 1945, Atomic Energy for Military Purposes, Princeton University Press, Princeton, New Jersey.

Van Arsdol, Theodore, 1972, Hanford: The City That Shook The World, Van Arsdol, Vancouver, Washington.

Williams, Robert C., and Cantelon, Philip L., eds., 1984, The American Atom, 1939-1984, University of Pennsylvania Press, Philidelphia, Pennsylvania. 


\section{WHC-MR-0435}

Sources (continued)

Additional information was gathered from historical and current issues of the following newspapers.

The Richland Villager, Richland, Washington.

The Tri-City Herald, Kennewick, Washington.

The Columbia Basin News, Pasco, Washington.

Oral history interviews with Richland residents and Hanford employees and retirees and their descendants also provided useful insights to historical events. 


\section{WHC-MR-0435}

This page intentionally left blank. 





